\title{
SPARC: a matricellular regulator of tumorigenesis
}

\author{
Shanna A. Arnold • Rolf A. Brekken
}

Received: 18 June 2009 /Accepted: 14 September 2009/Published online: 7 October 2009

(C) The Author(s) 2009. This article is published with open access at Springerlink.com

\begin{abstract}
Although many clinical studies have found a correlation of SPARC expression with malignant progression and patient survival, the mechanisms for SPARC function in tumorigenesis and metastasis remain elusive. The activity of SPARC is context- and cell-type-dependent, which is highlighted by the fact that SPARC has shown seemingly contradictory effects on tumor progression in both clinical correlative studies and in animal models. The capacity of SPARC to dictate tumorigenic phenotype has been attributed to its effects on the bioavailability and signaling of integrins and growth factors/chemokines. These molecular pathways contribute to many physiological events affecting malignant progression, including extracellular matrix remodeling, angiogenesis, immune modulation and metastasis. Given that SPARC is credited with such varied activities, this review presents a comprehensive account of the divergent effects of SPARC in human cancers and mouse models, as well as a description of the potential mechanisms by which SPARC mediates these effects. We aim to provide insight into how a matricellular protein such as SPARC might generate paradoxical, yet relevant, tumor outcomes in order to unify an apparently incongruent collection of scientific literature.
\end{abstract}

Supported by The Effie Marie Cain Scholarship in Angiogenesis Research (RAB), NIH grant R01CA118240 (RAB) and NIH training grant GM007062 (SA).

S. A. Arnold • R. A. Brekken $(\bowtie)$

Hamon Center for Therapeutic Oncology Research,

Division of Surgical Oncology

and Departments of Surgery and Pharmacology,

University of Texas Southwestern Medical Center,

6000 Harry Hines Blvd.,

Dallas, TX 75390-8593, USA

e-mail: rolf.brekken@utsouthwestern.edu
Keywords Angiogenesis · Extracellular matrix · Matricellular protein · Metastasis · Microenvironment . Osteonectin · SPARC $\cdot$ Tumor

$\begin{array}{ll}\text { Abbreviations } \\ \text { bFGF } & \text { Basic fibroblast growth factor } \\ \text { ECM } & \text { Extracellular matrix } \\ \text { FAK } & \text { Focal adhesion kinase } \\ \text { ILK } & \text { Integrin-linked kinase } \\ \text { NSCLC } & \text { Non-small cell lung cancer } \\ \text { PDAC } & \text { Pancreatic ductal adenocarcinoma } \\ \text { PDGF } & \text { Platelet-derived growth factor } \\ \text { SCLC } & \text { Small cell lung cancer } \\ \text { SiRNA } & \text { Small-interfering ribonucleic acid } \\ \text { SPARC } & \text { Secreted protein acidic and rich in cysteine } \\ \text { TGF } \beta & \text { Transforming growth factor beta } \\ \text { VEGF } & \text { Vascular endothelial growth factor }\end{array}$

\section{Introduction}

Historically, cancer research has focused on the molecular genetics and cell-autonomous behavior of malignant cells. However, understanding the interaction of cancer cells with their microenvironment has emerged as an essential step towards deciphering pathways that control transformation, primary tumor growth, metastasis, immune tolerance and therapeutic response (Desmouliere et al. 2004; Joyce and Pollard 2009; Kumar and Weaver 2009; Liotta and Kohn 2001; Lorusso and Ruegg 2008; Shan et al. 2009; Wernert 1997; Whiteside 2008; Zalatnai 2006). Cancer cells communicate with and elicit responses from the microenvironment at every stage of malignant progression. The tumor microenvironment is composed of tumor cells, extracellular 
matrix (ECM), stromal cells, microvessels and immune cells (Farrow et al. 2008; Jung et al. 2002). The ECM is an extracellular protein scaffold that determines tissue architecture and provides the structural framework for cells (Bosman and Stamenkovic 2003). Furthermore, the ECM is a remodeling network that regulates cell differentiation, survival, proliferation and migration (Larsen et al. 2006).

Deposition and remodeling of the ECM is regulated by a functional family of extracellular proteins known as matricellular proteins. Although primarily non-structural, matricellular proteins define and contribute to the structural integrity and composition of the ECM (Bornstein and Sage 2002). The capacity to influence assembly and turn-over of the ECM is a governing attribute of matricellular proteins, which is emphasized by their enhanced expression at sites of tissue remodeling and during wound-healing (Bornstein 2001; Bornstein and Sage 2002). Matricellular proteins can also direct cell fate, survival, adhesion and motility by functioning as adaptors between the ECM and the cell surface (Bornstein 2001; Bornstein and Sage 2002; Brekken and Sage 2001).

SPARC (secreted protein acidic and rich in cysteine), also known as osteonectin and BM-40, is a multifunctional secreted glycoprotein that exemplifies the matricellular class of proteins (Framson and Sage 2004). Expression of SPARC during mammalian development and tissue differentiation is robust but declines in the majority of organs after maturation (Bradshaw and Sage 2001). Ultimately, the expression of SPARC is limited post-development to tissues with high ECM turnover, such as bone and gut epithelia (Bradshaw and Sage 2001). However, SPARC is induced during wound-healing, at sites of angiogenesis, and by the stroma during tumorigenesis (Bornstein 2002; Mendis et al. 1998; Pen et al. 2007; Podhajcer et al. 2008; Reed et al. 1993). These observations suggest that SPARC functions as a regulator of tissue remodeling. In fact, the phenotype of SPARC-deficient mice validates the findings that SPARC controls tissue remodeling and is required for proper collagen matrix assembly and maturation (Bradshaw et al. 2003b; Brekken et al. 2003; Gruber et al. 2005). Mice lacking SPARC exhibit early cataractogenesis, lax skin, progressive osteopenia and a characteristic curly tail reminiscent of ECM defects (Framson and Sage 2004). Furthermore, collagen deposition and fibrillogenesis are altered in the dermis and lens capsule of SPARC-deficient mice (Bradshaw et al. 2003b; Yan et al. 2002).

Consistent with its participation in ECM assembly and turn-over, SPARC directly binds ECM proteins such as collagen and influences the secretion and activation of matrix metalloproteinases (MMPs) (Fujita et al. 2002; Gilles et al. 1998; McClung et al. 2007; Sage et al. 1989; Sasaki et al. 1998, 1999; Shankavaram et al. 1997). Moreover, SPARC interacts with or indirectly regulates several growth factors involved in angiogenesis and tissue remodeling including fibroblast growth factor (FGF), vascular endothelial growth factor (VEGF), plateletderived growth factor (PDGF), and transforming growth factor $\beta$ (TGF $\beta$ ) (Francki et al. 2004; Hasselaar and Sage 1992; Kato et al. 1998; Kupprion et al. 1998; Motamed et al. 2003; Raines et al. 1992).

By directing ECM deposition, cell-ECM interactions, and growth factor signaling, SPARC is well placed to regulate multiple hallmarks of cancer including angiogenesis, migration, proliferation and survival. As it is suggested that the tumor microenvironment is reminiscent of a wound that never heals and because SPARC is a prominent participant in wound-healing, it is not surprising that many cancers exhibit altered expression of SPARC (Clark and Sage 2008; Dvorak 1986; Framson and Sage 2004; Podhajcer et al. 2008). However, published data on the function of SPARC during tumorigenesis are inconsistent and often contradictory, even among the same tumor types. Thus, it seems that the capacity of SPARC to promote or inhibit tumor progression is dependent on the initiating cell-type, the tumor stage, and the context of the tumor microenvironment.

This article provides a comprehensive review of the literature on SPARC in human cancers and mouse models. We explore the function of SPARC in extracellular matrix deposition and fibrillogenesis, as well as in integrin and growth factor signaling. In an attempt to unify a divergent field, we conclude by proposing a working model to rationalize how SPARC contributes to seemingly paradoxical tumor outcomes.

\section{Tumor promotion}

SPARC displays oncogenic properties in many tumor types including gliomas, astrocytomas, melanomas, ductal carcinoma of the breast, colorectal carcinoma, clear-cell renal cell carcinoma, pancreatic ductal adenocarcinoma, and carcinoma of the prostate. Table 1 provides a list of those human correlative studies, along with associated mouse models and in vitro studies, which show evidence of SPARC as a tumor promoter.

Extensive data are available that show an increase in the expression of SPARC in glioblastomas, astrocytomas and meningiomas relative to that in normal brain, and reveal SPARC expression as a negative predictor of survival (Huang et al. 2000; Pen et al. 2007; Rempel et al. 1998; Rich et al. 2005). Furthermore, in vitro experiments demonstrate that endogenous and exogenous SPARC increase survival, adhesion, migration and invasion of glioblastoma cell lines (Golembieski et al. 1999, 2008; Kunigal et al. 2006; McClung et al. 2007; Rempel et al. 2001; Rich et al. 2003, 2005; Schultz et al. 2002; Seno et al. 2009; Shi et al. 2004, 

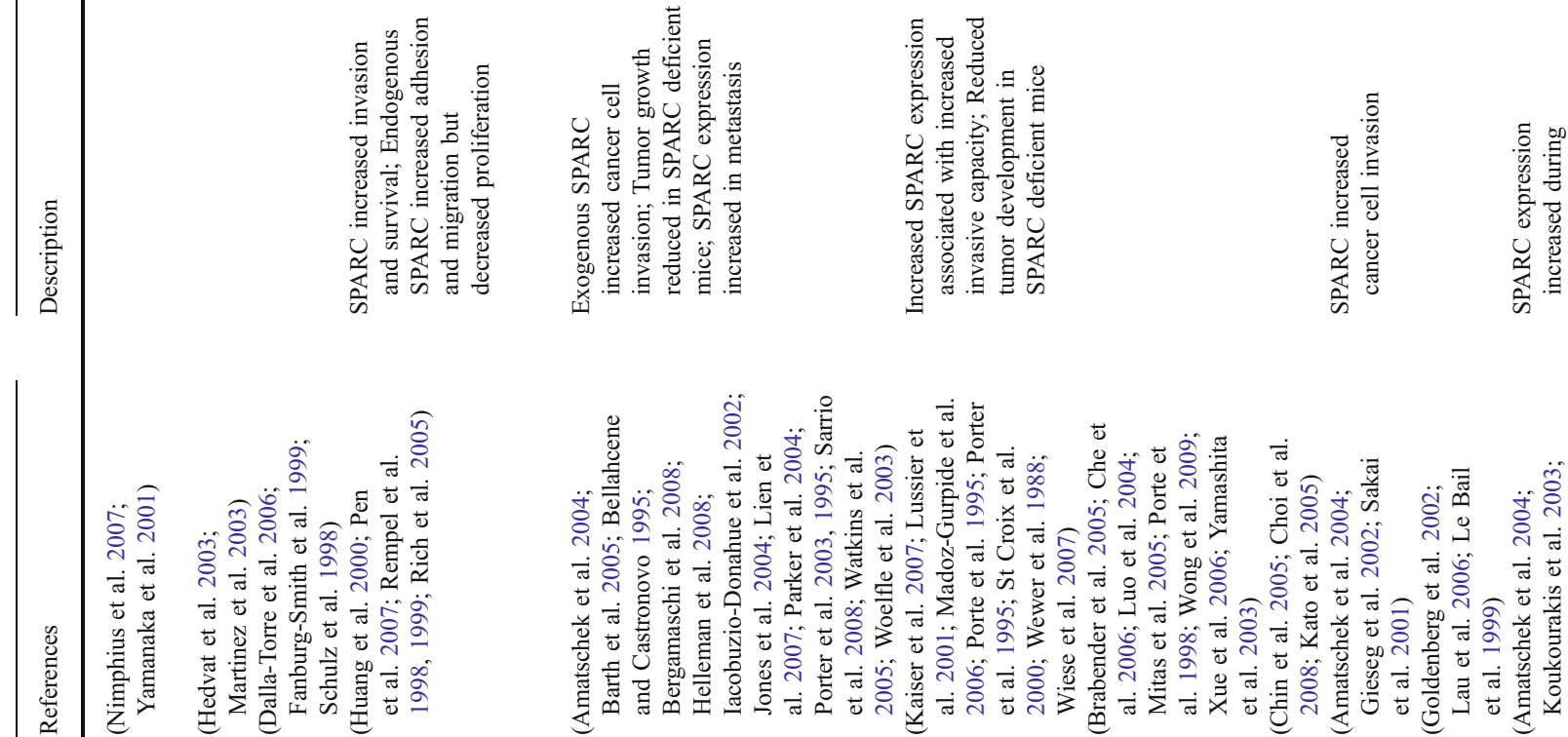

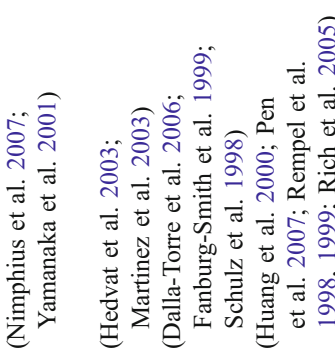

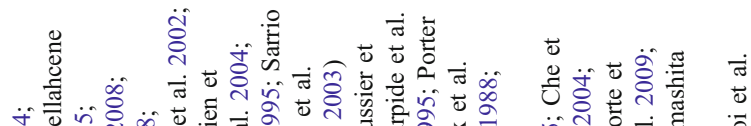

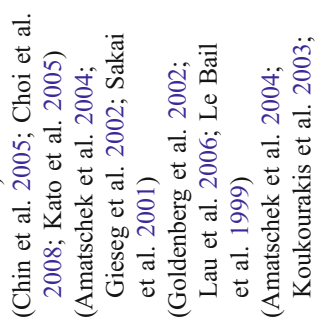

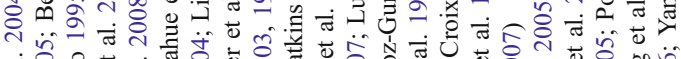

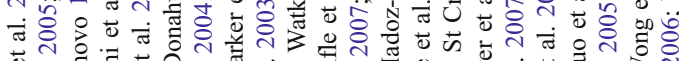

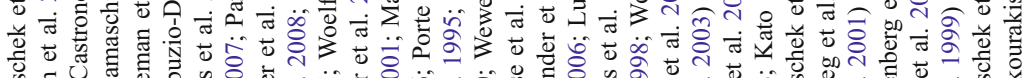

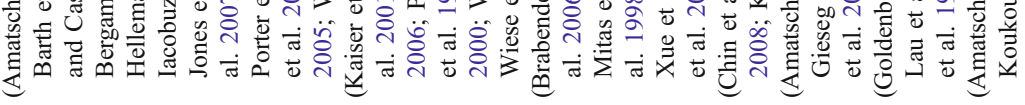
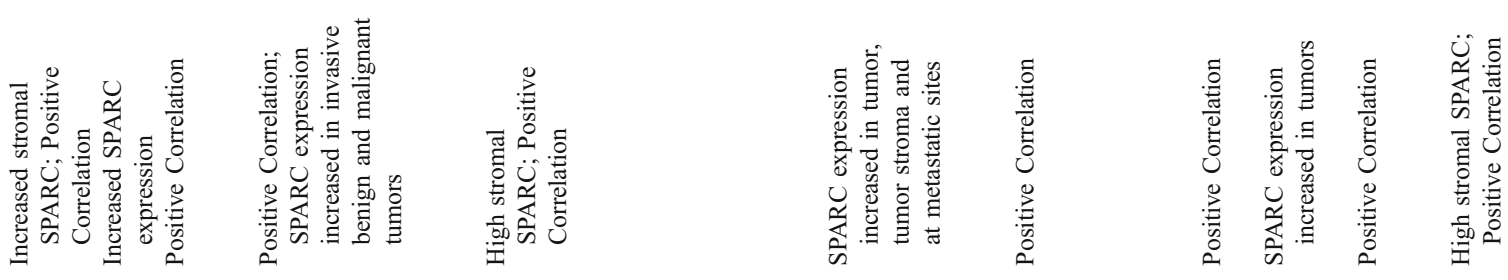

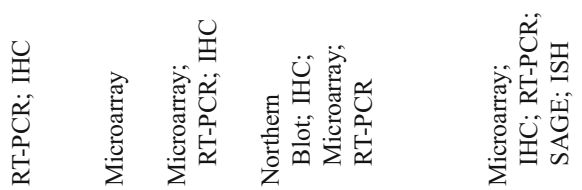

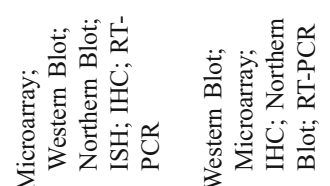
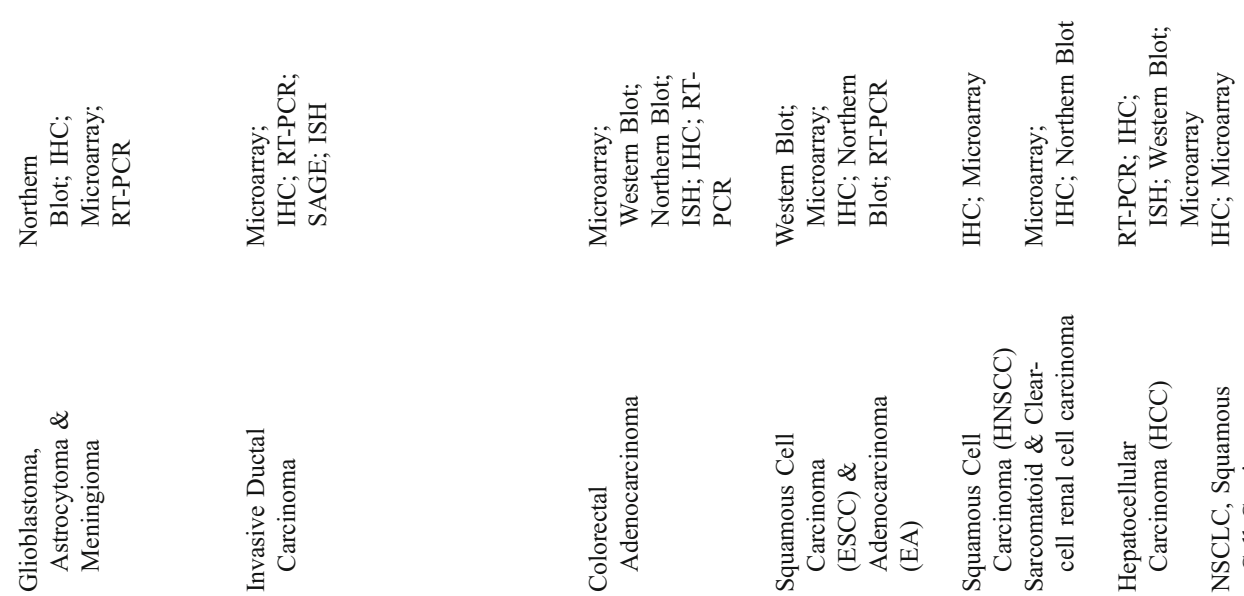

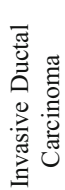

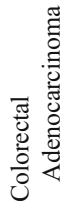

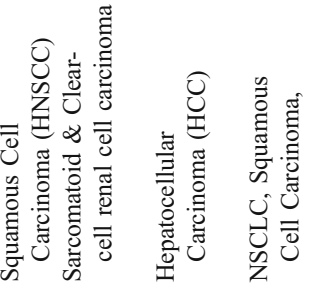

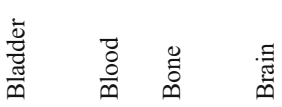

若

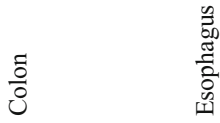
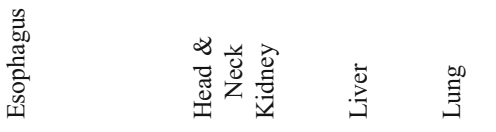


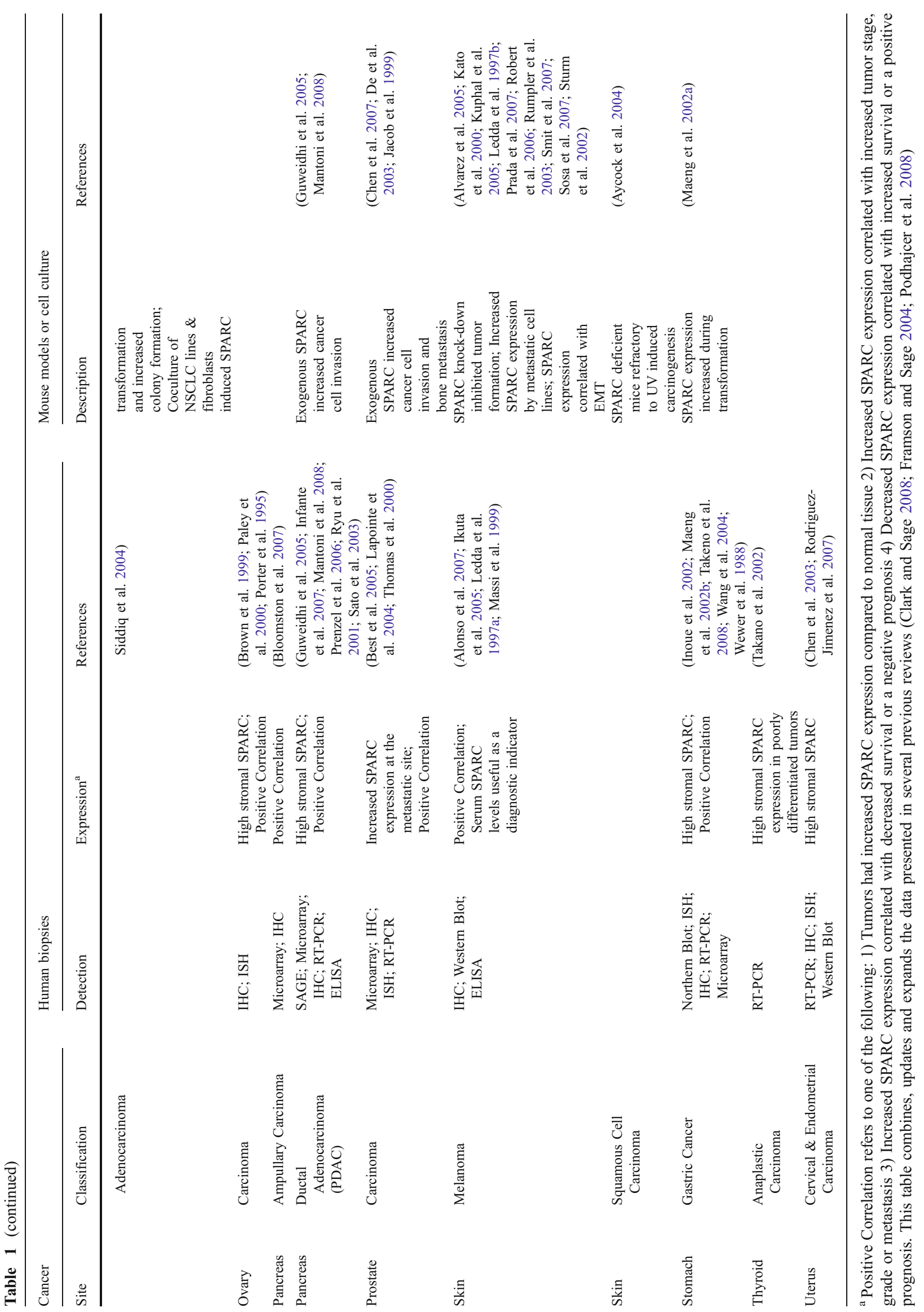


2007). Forced expression of SPARC by non-invasive glioma cells induces an invasive phenotype in mouse models of glioblastoma (Rich et al. 2003; Schultz et al. 2002). On the other hand, down-regulation of SPARC by siRNA in invasive glioma cell lines abrogates dissemination into surrounding brain regions after intracerebral injection into mice (Seno et al. 2009).

In invasive ductal carcinoma of the breast, the expression of SPARC is enhanced in tumor tissue compared to normal controls and an increased level of SPARC is associated with higher histological grade and advanced pathological stage (Amatschek et al. 2004; Barth et al. 2005; Bellahcene and Castronovo 1995; Bergamaschi et al. 2008; Helleman et al. 2008; Iacobuzio-Donahue et al. 2002; Jones et al. 2004; Lien et al. 2007; Parker et al. 2004; Porter et al. 2003, 1995; Sarrio et al. 2008; Watkins et al. 2005; Woelfle et al. 2003). Both exogenous administration and endogenous upregulation of SPARC enhance in vitro breast cancer cell invasion (Briggs et al. 2002; Campo McKnight et al. 2006; Gilles et al. 1998; Jacob et al. 1999; Zajchowski et al. 2001). In orthotopic and intravenous lung metastasis mouse models of breast cancer, SPARC expression is increased at metastatic sites and confers enhanced metastatic potential (Minn et al. 2005). Moreover, orthotopic breast tumor growth and lung metastasis are impaired in SPARC-deficient mice (Sangaletti et al. 2003, 2008).

Non-small cell lung cancers (NSCLC), including squamous cell carcinoma and adenocarcinoma, display an increased expression of SPARC relative to that in normal lung (Amatschek et al. 2004; Siddiq et al. 2004). Elevated SPARC expression by tumor stroma is associated with a poor prognosis in NSCLC (Koukourakis et al. 2003). Coculture of NSCLC cell lines with normal fibroblasts stimulates expression of SPARC (Fromigue et al. 2003). Furthermore, SPARC is upregulated during carcinogeninduced transformation of bronchial epithelial cells and is associated with enhanced anchorage-independent colony formation (Siddiq et al. 2004).

SPARC is expressed highly in pancreatic ductal adenocarcinoma (PDAC) at both primary and metastatic sites (Guweidhi et al. 2005; Prenzel et al. 2006; Ryu et al. 2001). In addition, patients with PDAC, whose tumor-associated stroma express high levels of SPARC, have a worse prognosis compared to those with no stromal SPARC expression, which results in a relative hazard ratio of 1.89 (Infante et al. 2007; Mantoni et al. 2008). In vitro, exogenous SPARC enhances, while SPARC knock-down reduces, invasion of human pancreatic cancer cells (Guweidhi et al. 2005; Mantoni et al. 2008).

An elevated expression of SPARC is also found in primary and metastatic melanoma (Alonso et al. 2007; Ledda et al. 1997a). The expression of SPARC in cutaneous melanomas correlates significantly with an increase in disease progression and metastatic incidence, as well as with a decrease in survival (Alonso et al. 2007; Massi et al. 1999). Elevated SPARC levels are found in the serum of patients with malignant melanoma, a marker used to successfully identify $33 \%$ of melanoma patients including those with early stage disease (Ikuta et al. 2005). Human melanoma cell lines also express high levels of SPARC (Ledda et al. 1997a). Forced expression of SPARC induces motility of normal human melanocytes and enhances invasion of melanoma cells (Robert et al. 2006; Smit et al. 2007). Antisense suppression of SPARC reduces the in vitro adhesive and invasive capacity of melanoma cell lines, and abrogates in vivo tumor formation (Alvarez et al. 2005; Ledda et al. 1997b; Prada et al. 2007; Robert et al. 2006; Smit et al. 2007; Sosa et al. 2007). Lastly, metastatic variants of mouse melanoma cell lines show differential expression of SPARC; whereby, those with higher metastatic potential or those that demonstrate aggressive behavior express and/or secrete increased amounts of SPARC relative to low-metastatic variants (Kato et al. 2000; Rumpler et al. 2003).

\section{Tumor suppression}

SPARC also shows characteristics of a tumor suppressor in many cancers including acute myeloid leukemia, neuroblastoma, carcinoma of the breast, colorectal adenocarcinoma, hepatocellular carcinoma, non-small cell and small cell lung cancer, carcinoma of the ovaries and pancreatic ductal adenocarcinoma. Table 2 presents a comprehensive list of human correlative studies, associated mouse models and in vitro studies that support the capacity of SPARC to impede tumor progression.

The promoter of the SPARC gene is hypermethylated in many epithelial cancers, effectively reducing SPARC production by tumor cells and supporting the idea that SPARC is tumor-suppressive in a variety of cancers (Table 2). SPARC promoter methylation is reported in colorectal, non-small cell and small cell lung, ovarian, pancreatic, prostate and uterine cancers (Brune et al. 2008; Cheetham et al. 2008; Hong et al. 2008; Rodriguez-Jimenez et al. 2007; Sato et al. 2003; Socha et al. 2009; Sova et al. 2006; Suzuki et al. 2005; Wang et al. 2005; Yang et al. 2007). In most cases, SPARC promoter methylation correlates with a poor prognosis and/or decreased survival.

The SPARC promoter is hypermethylated in 80 $100 \%$ of colorectal adenocarcinomas and correlates with a worse prognosis (Cheetham et al. 2008; Yang et al. 2007). In addition, approximately $71 \%$ of human colorectal cancer cell lines are methylated within the SPARC locus (Cheetham et al. 2008; Yang et al. 2007). Further evidence comes from data showing chemoresistant human 
colorectal cancer cells significantly downregulate SPARC production (Tai et al. 2005). More importantly, reexpression of SPARC or exogenous administration of SPARC restores chemosensitivity in resistant cell lines and leads to tumor regression in xenograft models when combined with chemotherapy (Cheetham et al. 2008; Taghizadeh et al. 2007; Tai et al. 2005).

SPARC gene methylation occurs in $71 \%$ of non-small cell lung cancers (NSCLC) and 33\% of small cell lung cancers (SCLC) (Suzuki et al. 2005). The promoter methylation status of SPARC is an independent adverse prognostic factor with a relative risk of 4.65 in lung adenocarcinoma (Suzuki et al. 2005). Similar to human biopsies, $75 \%$ of NSCLC and $25 \%$ of SCLC cell lines show evidence of SPARC methylation (Suzuki et al. 2005). Furthermore, treatment of human lung cancer cells with the nonsteroidal anti-inflammatory drug NS398 reduces invasion by restoring SPARC expression through promoter demethylation, an effect that is blocked by an anti-SPARC antibody (Pan et al. 2008).

SPARC also functions as a tumor suppressor in ovarian carcinoma. Malignant epithelial cells in ovarian carcinoma tissue samples exhibit reduced SPARC immunoreactivity (Yiu et al. 2001). This reduction in SPARC expression in the tumor compartment is due to epigenetic silencing; whereby, $68 \%$ of ovarian carcinomas display aberrant methylation of the SPARC promoter (Socha et al. 2009). In fact, decreasing levels of SPARC protein in the malignant cells corresponds with disease progression (Socha et al. 2009). Ovarian cancer cell lines also show reduced expression and secretion of SPARC compared to normal ovarian epithelial cells, which express and secrete high levels of SPARC (Mok et al. 1996; Socha et al. 2009; Yiu et al. 2001). Moreover, forced expression or exogenous addition of SPARC attenuates in vitro proliferation and in vivo tumor growth of ovarian carcinoma cells (Mok et al. 1996; Socha et al. 2009; Yiu et al. 2001). In a mouse model of peritoneal ovarian carcinomatosis, SPARC-null mice experience diminished survival, enhanced peritoneal dissemination and increased accumulation of ascitic fluid compared to wild-type animals (Bull Phelps et al. 2009; Said and Motamed 2005; Said et al. 2007a, b).

In pancreatic ductal adenocarcinoma, malignant epithelial cells within the tumor often downregulate SPARC expression (Sato et al. 2003). SPARC methylation occurs in $91 \%$ of human infiltrating pancreatic adenocarcinoma, $88 \%$ of primary human pancreatic carcinoma xenografts and 94\% of human pancreatic cancer cell lines (Brune et al. 2008; Hong et al. 2008; Sato et al. 2003). Gradual loss of SPARC expression and methylation in pancreatic ductal epithelial cells is also seen in the progression of intraductal papillary mucinous neoplasms, precursors to invasive adenocarcinoma (Hong et al. 2008). Treatment with exogenous SPARC reduces pancreatic cancer cell proliferation (Guweidhi et al. 2005; Sato et al. 2003). Additionally, subcutaneous and orthotopic tumor growth of murine pancreatic adenocarcinoma cells is enhanced in SPARCnull mice relative to wild-type counterparts (Arnold et al. 2008; Puolakkainen et al. 2004).

Lastly, SPARC expression is disregulated in uterine cancers. In human cervical carcinoma, SPARC is aberrantly methylated in $86 \%$ of cancer specimens and only in $5 \%$ of normal tissue (Sova et al. 2006). Furthermore, the frequency of SPARC hypermethylation is significantly increased in high-grade cervical lesions compared to low-grade neoplasias and normal cervical controls (Kahn et al. 2008; Sova et al. 2006). Endometrial cancers also display SPARC promoter methylation in $66 \%$ of human samples, as well as, a reduction in the expression of SPARC by the malignant epithelial cell compartment (Rodriguez-Jimenez et al. 2007).

\section{Compartmentalized expression}

Several epithelial cancers present with contradictory compartmentalized SPARC expression; whereby, SPARC is upregulated by the intra- and peritumoral stroma but downregulated by the malignant cells. This paradoxical pattern of SPARC expression is observed in breast, colorectal, lung, ovarian, pancreatic and endometrial cancers (Barth et al. 2005; Iacobuzio-Donahue et al. 2002; Paley et al. 2000; Rodriguez-Jimenez et al. 2007; Sato et al. 2003; Suzuki et al. 2005; Yang et al. 2007; Yiu et al. 2001). Whereas SPARC is highly expressed by normal breast and colonic epithelium, invasive ductal breast and colorectal carcinoma show dramatically reduced expression by the malignant epithelial cells (Fig. 1). However, the tumorreactive stroma displays intense SPARC immunoreactivity (Fig. 1) (Barth et al. 2005; Yang et al. 2007). Although the tumor compartment exhibits reduced SPARC production in lung and pancreatic cancers due to promoter hypermethylation, infiltrating stromal cells respond with a compensatory upregulation of SPARC (Sato et al. 2003; Suzuki et al. 2005). Overall SPARC levels are elevated in endometrial carcinoma, but this over-expression is limited to the stroma; whereas, the tumor cells themselves display attenuated SPARC expression (Rodriguez-Jimenez et al. 2007).

In regards to colorectal, lung, ovarian, pancreatic and endometrial cancers, the contradictory compartmentalized expression of SPARC is a result of the loss of SPARC expression by the malignant epithelial cells due to promoter hypermethylation, as discussed in the previous section (Barth et al. 2005; Paley et al. 2000; Rodriguez-Jimenez et al. 2007; Sato et al. 2003; Suzuki et al. 2005; Yang et al. 2007; Yiu et al. 2001). Furthermore, tumor cells may act in a paracrine 


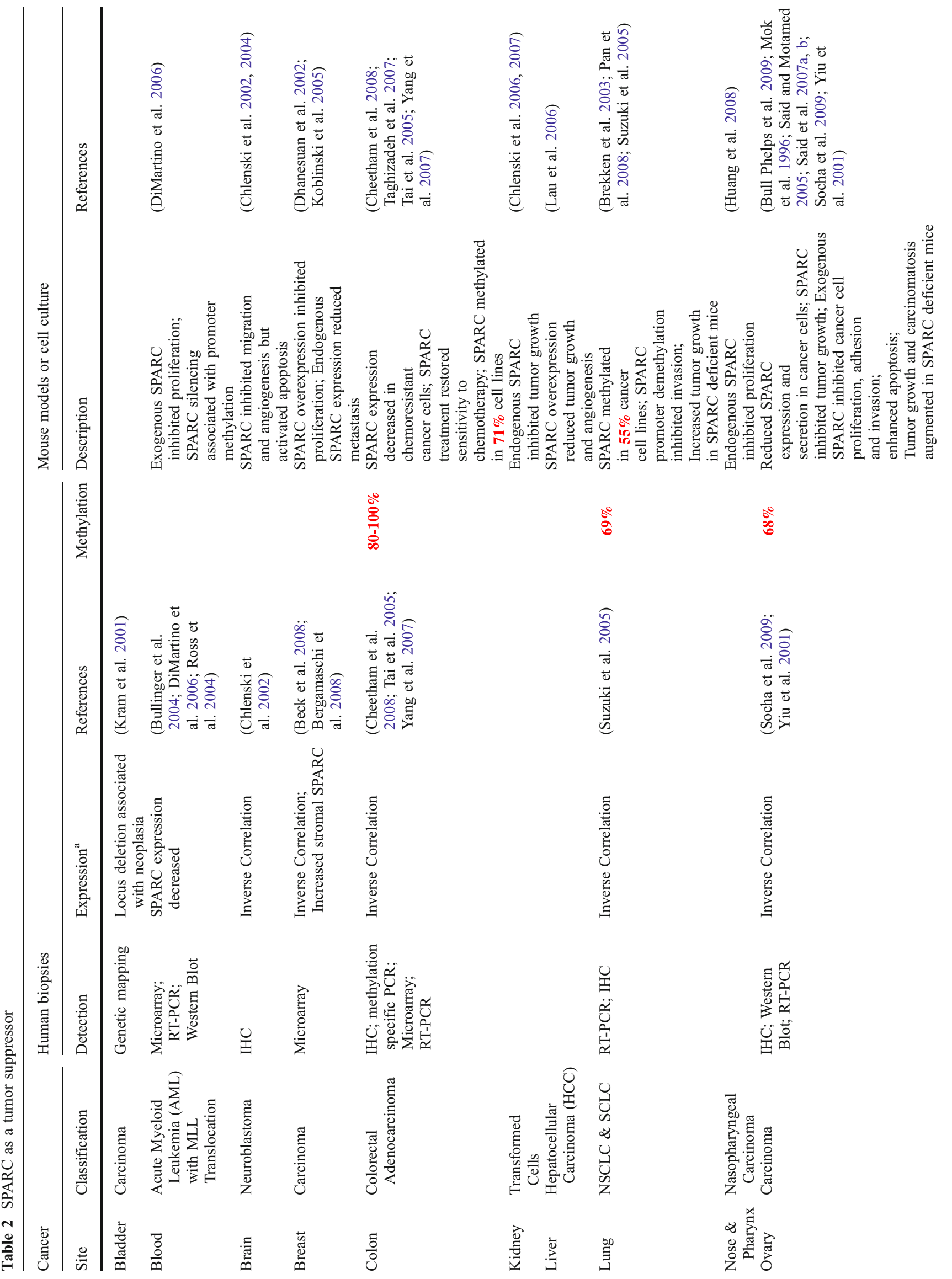




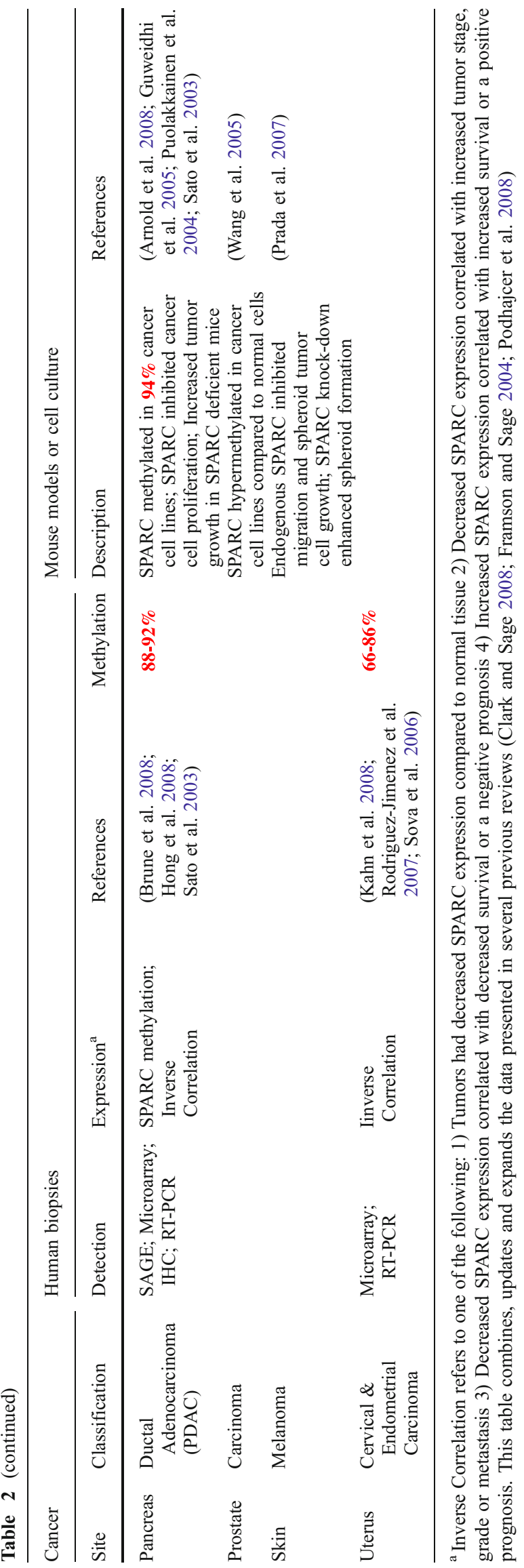

fashion to induce SPARC expression by the surrounding stroma. Indeed, fibroblasts isolated from normal pancreas display augmented SPARC expression when cocultured with pancreatic cancer cells (Sato et al. 2003).

Therefore, the heterogeneity and compartmentalization of SPARC expression can explain contradictory results and correlations with SPARC among identical cancers and between differing tumor types. What the data suggest is that the effect of SPARC on tumor progression and patient outcome is both tumor-type and context dependent. In other words, the source and localization of SPARC in the tumor microenvironment contributes to the complexity of SPARC influence during tumorigenesis.

\section{Extracellular matrix}

The primary function of the ECM is to maintain tissue shape and to provide the cellular compartment with structural support (Bosman and Stamenkovic 2003). However, the ECM is not just a passive bystander. It is a remodeling network that contributes substantially to tumor progression and metastasis by influencing cell adhesion, migration, differentiation, proliferation and survival (Engbring and Kleinman 2003; Ioachim et al. 2002; Streuli 2009; Streuli and Akhtar 2009; Timar et al. 2002). By binding to adhesion receptors such as integrins, the ECM can communicate directly with the cell and influence signaling responses (Berrier and Yamada 2007; Juliano 2002; Moser et al. 2009; Stupack 2007). The ECM can also regulate cell function by harboring matrikines and dictating bioavailability of cytokines (Schultz and Wysocki 2009). SPARC expression is increased concomitantly with activation of ECM deposition (Framson and Sage 2004). In addition, SPARC directly interacts with the ECM by binding basement membrane collagen IV and fibrillar collagens I, III and V (Sage et al. 1989; Sasaki et al. 1998; Sasaki et al. 1999).

There is ample evidence that SPARC is required for proper secretion, deposition and fibrillogenesis of collagen during development, wound-healing and tumor progression. SPARC-deficient mice exhibit a range of phenotypes as a result of disruption in ECM deposition and organization, including early cataract formation, accelerated dermal wound-healing, osteopenia and a curly tail (Bradshaw and Sage 2001). Premature cataractogenesis is observed in two independently generated SPARC-null mouse colonies, and is caused by disorganized deposition of collagen IV and laminin in the lens epithelial basement membrane (Gilmour et al. 1998; Norose et al. 1998; Yan et al. 2002, 2003). SPARC-null mice also show deficiencies in connective tissue, such as decreased levels of collagen I in skin, adipose, heart and bone (Bradshaw et al. 2003a, c; Delany et al. 2003). In addition to the reduction in collagen 
a

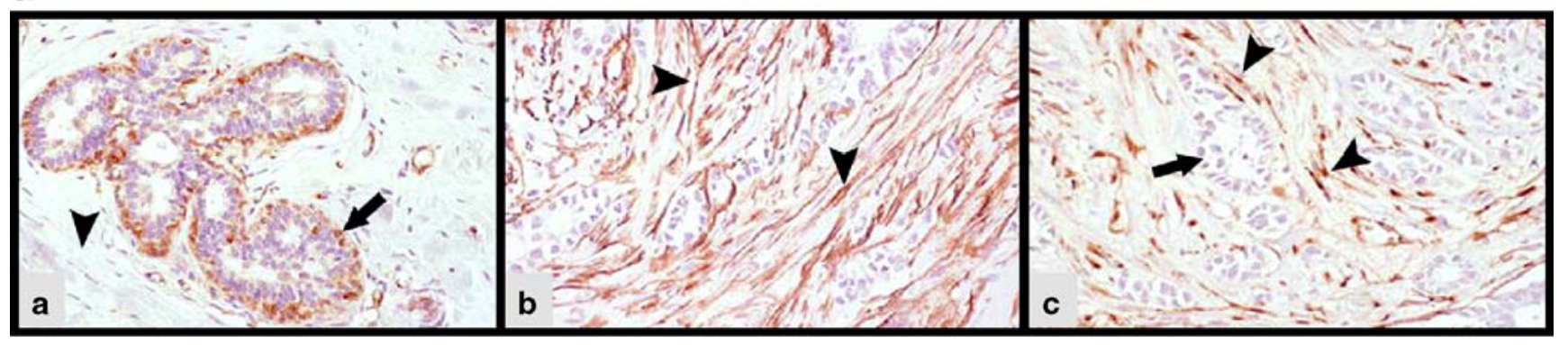

b

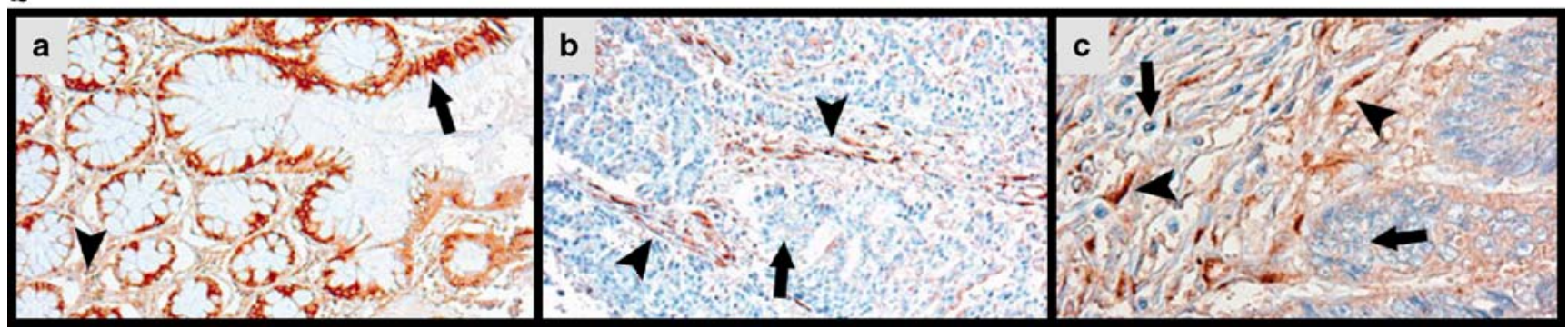

Fig. 1 Compartmentalized SPARC expression in human cancer. a Immunohistochemical staining of human biopsies of normal breast and invasive ductal adenocarcinoma, adapted from Barth et al. (2005) Copyright (C) Springer. Reprinted with permission of Springer-Verlag Berlin Heidelberg New York, A member of BertelsmannSpringer Science + Business Media GmbH (a) SPARC is expressed in myoepithelial cells (arrow) and by a few stromal cells in the ducts of normal breast. However, much of the stroma lacks SPARC expression (arrowhead) (b) Staining for $\alpha$-SMA in the tumorassociated stroma (arrowheads) reveals activated fibroblasts also positive for (c) SPARC immunoreactivity (arrowheads). The arrow points to malignant epithelial cells lacking SPARC expression. b Immunohistochemical analysis of SPARC expression in colonic mucosae and colorectal carcinomas, adapted from Yang et al. (2007) Copyright (C) 2005 Wiley-Liss, Inc. Reprinted with permission of Wiley-Liss, Inc., A Wiley Company. (a) Normal colonic epithelial cells (arrow) strongly express SPARC, while there is only minimal SPARC expression in the surrounding stroma (arrowhead). $(b, c)$ SPARC expression by the carcinoma cells (arrows) is dramatically reduced or absent, while tumor stromal cells display strong expression of SPARC (arrowheads) (c) Higher magnification deposition, collagen fibrils in the skin of SPARC-deficient mice are uniformly smaller in diameter compared to the heterogeneous fibrils found in wild-type dermis (Bradshaw et al. 2003b). Reduction in collagen deposition and fibrillogenesis in SPARC-null mice leads to accelerated dermal wound-healing, presumably due to increased contractility (Bradshaw et al. 2002, 2003c).

Not only do SPARC-deficient mice display alterations in the ECM during development and normal tissue turnover but, in the absence of SPARC, there is also a diminished foreign-body and tumor response in regard to encapsulation. Implantation of foreign material into mice elicits a stromal response that essentially encapsulates this material in a wall of ECM. However, the collagen capsule deposited in response to foreign-body implantation is markedly reduced in thickness in SPARC-null compared to wild-type mice (Puolakkainen et al. 2003). Furthermore, analogous to the alterations observed during development, the collagen fibrils bordering the implanted material are uniformly smaller in diameter and less mature in the absence of SPARC relative to fibers deposited in wild-type mice (Puolakkainen et al. 2003).
Similarly, many solid tumors show encapsulation demarcating the tumor from normal tissue. Subcutaneous tumor models of murine lung carcinoma, lymphoma and pancreatic adenocarcinoma present with enhanced growth in SPARC-null mice compared to wild-type controls (Brekken et al. 2003; Puolakkainen et al. 2004). Moreover, tumors grown in the absence of host SPARC exhibit deficits in collagen deposition and fibrillogenesis at the tumor capsule, as well as in intratumoral connective tissue highways (Brekken et al. 2003; Puolakkainen et al. 2004). There are also alterations in the composition of noncollagenous ECM proteins, such as laminin, in tumors grown in SPARC-null animals (Brekken et al. 2003). In addition, murine pancreatic cancer cells injected orthotopically into SPARC-null mice grow larger and metastasize more frequently than those in wild-type mice, thus highlighting the importance of SPARC function and ECM composition in tumor progression (Arnold et al. 2008). The fact that the tumor cells, but not the infiltrating stromal cells, express and secrete SPARC in the aforementioned studies also supports the observation that the effect of SPARC on tumorigenesis is context- and cell-typedependent (Arnold et al. 2008; Brekken et al. 2003; 
Puolakkainen et al. 2004). Thus, SPARC can influence tumor progression and metastasis by controlling deposition and composition of the ECM. Moreover, the diverse actions of SPARC in differing tumors may be a result of distinctive ECM profiles.

\section{Integrin signaling}

The ECM directly interacts with cells through a family of cell-surface receptors known as integrins (Moser et al. 2009). Integrins anchor cells to the ECM, signal in response to ECM ligation ("outside-in" signaling) and regulate the interactions of the ECM in response to intracellular cues ('inside-out' signaling) (Moser et al. 2009). Integrin signaling pathways substantially interact with growth factor receptor pathways to dictate cellular events, such as survival, proliferation, adhesion and migration, all of which contribute to tumor growth and metastasis. Integrin complexes can also cluster directly with growth factor receptors. Furthermore, proper cytokine responses require intact integrin activation and signal propagation (Eliceiri 2001; Porter and Hogg 1998; Somanath et al. 2009; Streuli and Akhtar 2009).

Numerous studies suggest that SPARC regulates integrin signaling and the ability of integrins to interact with structural components of the ECM. SPARC induces cell rounding or an intermediate state of adhesion in several cell types, in vitro, including endothelial and mesenchymal cells (Bradshaw et al. 1999; Sage et al. 1989). This effect is due to disruption of focal adhesions (Bradshaw et al. 1999). In addition, many studies contribute to the emerging idea that SPARC influences downstream components of integrin signaling, specifically the activation of integrin linked kinase (ILK). Fibronectininduced ILK activation and stress-fiber formation are reduced in primary lung fibroblasts isolated from SPARC-null mice and restored by forced SPARC expression (Barker et al. 2005). Furthermore, SPARC promotes cell survival of lens epithelial cells under serumdeprivation by enhancing ILK activation (Weaver et al. 2008). Moreover, recent publications report that SPARC binds integrin $\beta 1$ with its copper-binding domain; thereby, directly affecting integrin/ILK signaling (Nie et al. 2008; Weaver et al. 2008).

The influence of SPARC on integrin/ILK responses is also observed in several cancer cell lines. SPARC increases survival and induces an invasive phenotype in human glioma cells (Schultz et al. 2002; Shi et al. 2004, 2007). However, targeting SPARC with short-hairpin RNA reduces cell survival and invasion, as well as attenuates the activity of ILK, focal adhesion kinase (FAK) and protein kinase B (Akt) (Shi et al. 2007). Moreover, SPARCinduced invasion and survival is abrogated by downregulation of ILK and FAK (Shi et al. 2007). Total ILK expression is also found to be increased in glioma cells that are forced to express SPARC (Golembieski et al. 2008). In human ovarian cancer cells, SPARC inhibits adhesion, invasion and proliferation by reducing the surface localization and/or clustering of $\alpha \mathrm{v}, \beta 1, \beta 3$ and $\beta 5$ integrins (Said et al. 2007a). SPARC attenuates integrin $\alpha \mathrm{v}$ - and $\beta 1$ induced proliferation in murine ovarian cancer cells. Furthermore, murine ovarian cancer cells adhere more readily to peritoneal explants and peritoneal mesothelial cells isolated from SPARC-null mice compared to wild-type counterparts (Said et al. 2007b). This effect is blocked by antibodies against $\alpha \mathrm{v} \beta 3$ and $\beta 1$ integrins (Said et al. 2007b).

Together, these data reveal that SPARC influences integrin clustering and activation, as well as the ability of integrins to interact with structural components of the ECM. Moreover, SPARC potentially dictates if and how integrins converse with and reinforce other signaling cascades. Therefore, it is not surprising that SPARC elicits such diverse effects on tumorigenesis, given the fact that it possesses the ability to control the pleiotropic interactions and functions of integrins.

\section{Growth factor and cytokine signaling}

Cross-talk between malignant cells and the surrounding stromal compartment induces ECM remodeling, angiogenesis, immune recruitment and metastasis (Davis and Senger 2005). Growth factors and their associated receptors are one way by which communication occurs between cellular compartments. It is established that SPARC modulates the activity of several growth factors including basic fibroblast growth factor (bFGF), platelet-derived growth factor (PDGF), vascular endothelial growth factor (VEGF), and transforming growth factor beta (TGF $\beta$ ) (Francki et al. 2004; Hasselaar and Sage 1992; Kupprion et al. 1998; Raines et al. 1992). Although SPARC does not bind bFGF directly, it inhibits bFGF-induced migration of endothelial cells (Hasselaar and Sage 1992). SPARC binds PDGF and dose-dependently inhibits ligand binding and activation of PDGF receptors on human dermal fibroblasts (Raines et al. 1992). In addition, PDGF-stimulated proliferation of human arterial vascular smooth muscle cells is decreased in the presence of SPARC (Motamed et al. 2002).

Similar to PDGF, SPARC binds VEGF directly and prevents activation of VEGFR1 (Kupprion et al. 1998; Nozaki et al. 2006). This interaction attenuates VEGF- 
induced proliferation of microvascular endothelial cells (Kupprion et al. 1998). On the other hand, VEGF induces the expression of SPARC in human vascular endothelial cells (Kato et al. 2001). Therefore, the induction of SPARC by VEGF stimulation might be a negative regulatory feedback mechanism. In support, VEGF production is enhanced in dermal fibroblasts and subcutaneous polyvinyl alcohol sponges from SPARC-null mice relative to wildtype controls, which results in a greater angiogenic response in the absence of SPARC (Bradshaw et al. 2001). When injected into the brain of nude rats, SPARC-expressing human glioblastoma cells reduce VEGF expression and angiogenesis related to tumor formation in comparison to SPARC-negative glioma cells (Yunker et al. 2008). In a mouse model of ovarian cancer, peritoneal dissemination and lethality is augmented in the absence of host-derived SPARC, which corresponds to VEGF accumulation in ascitic fluid (Said and Motamed 2005; Said et al. 2007b).

SPARC is also implicated in the regulation of TGF $\beta$ (Francki et al. 2004; Schiemann et al. 2003). TGF $\beta$ is a master regulator of wound-healing and fibrosis by inducing the synthesis of several ECM proteins including collagen and fibronectin (Verrecchia and Mauviel 2007). Ample data demonstrate that TGF $\beta$ induces SPARC expression (Ford et al. 1993; Pavasant et al. 2003; Reed et al. 1994; Wrana et al. 1991). However, there is also evidence that SPARC regulates the expression and activity of TGF $\beta$, suggesting that there is a reciprocal regulatory feedback loop between SPARC and TGF $\beta$. SPARC induces the expression and secretion of TGF $\beta 1$ in rat mesangial cells in vitro and in vivo (Bassuk et al. 2000). The synthesis of collagen I and TGF $\beta-1$ is diminished in mesangial cells isolated from SPARC-null mice compared to those from wild-type mice, but is restored by the exogenous addition of SPARC (Francki et al. 1999). Moreover, SPARC enhances the stimulatory effects of TGF $\beta 1$ on mesangial cells by directly interacting with the TGF $\beta /$ TGF $\beta$ RII complex (Francki et al. 2004). Likewise, SPARC augments the inhibitory functions of TGF $\beta 1$ in epithelial cells by stimulating smad $2 / 3$ phosphorylation (Schiemann et al. 2003).

Considering that growth factors such as bFGF, PDGF, VEGF and TGF $\beta$ are important contributors to tumor progression, angiogenesis and metastasis, it is clear that the interaction of SPARC with these signaling pathways influences its ability to dictate many aspects of tumorigenesis. In addition, SPARC interaction with growth factors, such as TGF $\beta$, that have a dichotomous effect on the progression of solid tumors, explains the ability of SPARC to influence human cancers in such apparently paradoxical ways (Tian and Schiemann 2009).

\section{Conclusions}

SPARC can modulate ECM assembly, integrin activity and growth factor signaling; thereby, controlling a range of cellular functions including adhesion, proliferation, survival and migration. Therefore, it is not surprising that the expression of SPARC is dysregulated in many human cancers and that this dysregulation contributes to patient outcome. Although there is no unifying mechanism, as yet, for the effects of SPARC in tumorigenesis, this protein clearly influences the microenvironment and signaling pathways involved in disease progression. The concept that SPARC regulates cell function through modulation of integrin binding and activation is provocative, since integrin receptors have also been implicated in each of the cellular processes influenced by SPARC. To date, no bona fide signaling receptor has been identified for SPARC. However, given that SPARC directly binds to the ECM, integrins and growth factor/receptor complexes, we propose that SPARC functions as an extracellular scaffolding protein; whereby, SPARC dictates the activating threshold at which integrin and growth factor-signaling processes propagate cellular events (Fig. 2). It is known that there is extensive cross-talk between integrinand growth factor -signaling pathways, and that integrin signaling is required for proper cellular responses to cytokine stimulation (Eliceiri 2001; Porter and Hogg 1998; Somanath et al. 2009; Streuli and Akhtar 2009). In addition, integrins can associate directly with growth factor receptors (Eliceiri 2001; Porter and Hogg 1998; Somanath et al. 2009; Streuli and Akhtar 2009). By controlling the clustering and activation of integrins, as well as, the association and crosstalk with growth factor receptors, SPARC might function as a rheostat for cellular signaling and behavior. Thus, factors controlling the effects of SPARC on any particular cell would consist of the ECM composition, integrin profile, cytokine milieu, cell type (e.g. mesenchymal, endothelial or epithelial), and SPARC concentration/cell-surface localization. This concept provides a potential explanation for how SPARC modulates so many cellular events, and for why the considerable data collected in regard to SPARC during tumorigenesis have failed to elucidate any specific and consistent mechanism.

It is difficult to determine a mechanism when numerous confounding factors are involved, and when many groups publish seemingly contradictory data on the function of SPARC. However, we propose that this collection of incongruous data is a result of the dependence of SPARC function on multiple factors associated with its role as an extracellular scaffolding protein and signaling rheostat. Future experiments should aim to validate whether SPARC controls the formation of integrin- and growth factor-receptor complexes and, if so, to clarify how these 


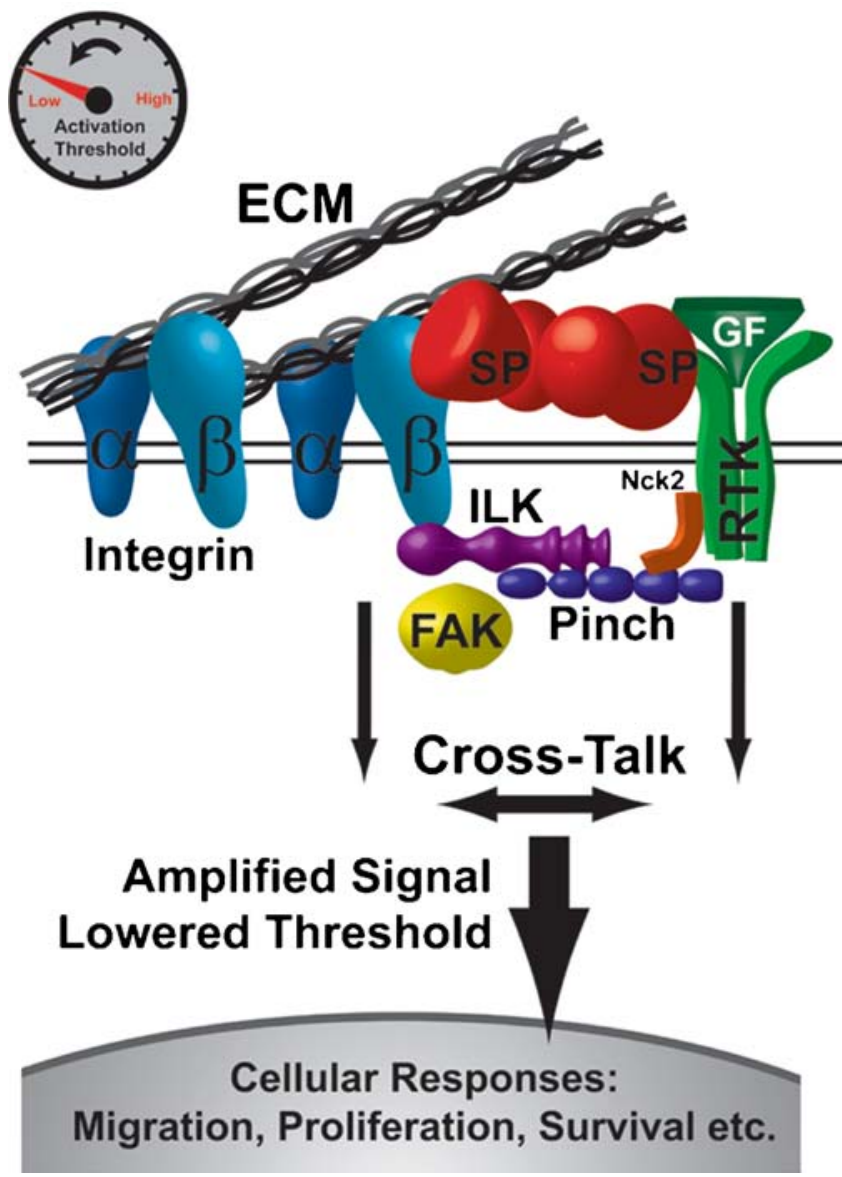

Fig. 2 SPARC as an extracellular scaffolding protein and rheostat. We propose that SPARC $(S P)$ acts as an extracellular scaffolding protein; whereby, SPARC controls the interactions and cross-talk between the extracellular matrix $(E C M)$, integrins $(\alpha, \beta)$ and growth factor receptors (RTK). By controlling integrin clustering and activation, as well as, integrin communication with growth factor receptors, SPARC can function as a rheostat for signaling and cellular response. (Left) SPARC may decrease the activating threshold of certain growth factors (GF) by enhancing complex formation and cross-talk between integrins and growth factor receptors. Integrin-linked kinase $(I L K)$, Pinch, and Nck2 link integrins and growth factor receptors, intracellularly, to form localized signaling cascades, while SPARC acts as an extracellular scaffold to reinforce this complex. Focal adhesion kinase $(F A K)$ is just one example of a signaling molecule located downstream

associations control cellular responses to various cytokines. Additionally, it is pertinent to determine how SPARC dictates the activities of each cell type in the tumor microenvironment. Given that SPARC contributes to such a diverse and conflicting range of activities, targeting SPARC globally in human cancer has the potential to present with adverse off-target effects. Therefore, clarification of the molecular mechanisms that involve the role of SPARC during tumorigenesis is necessary in order to develop effective strategies that can target SPARC therapeutically and exploit the idea of

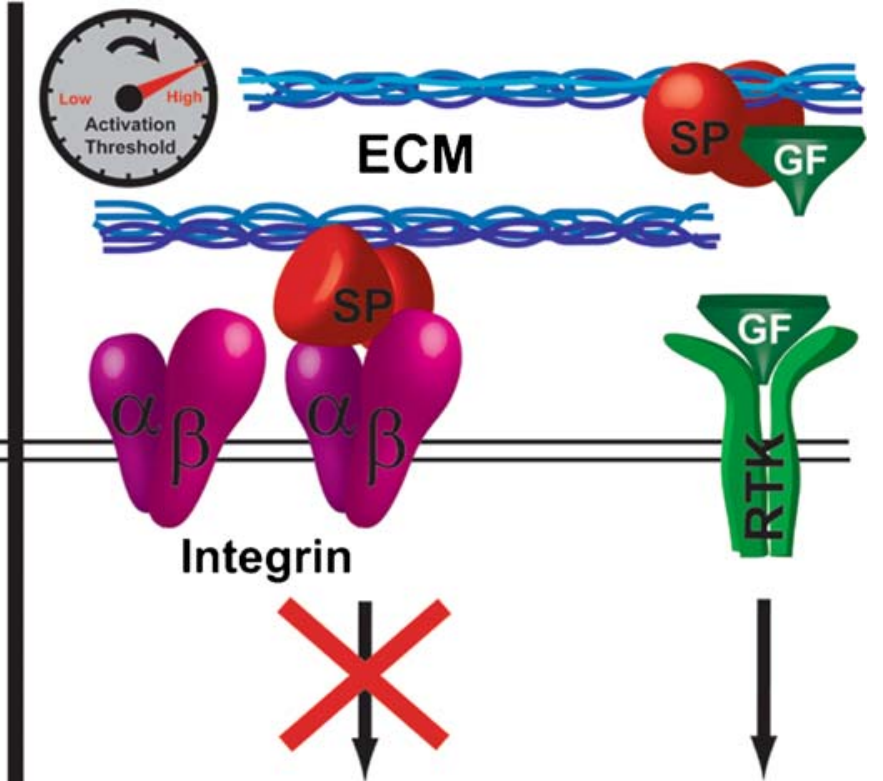

No Cross-Talk No Signal Amplification
Raised Threshold

\section{Reduced Cellular Response}

of both integrins and growth factor receptors whose activation is influenced by SPARC. Ultimately, integrin-growth factor receptor cross-talk leads to signal amplification and enhanced cellular responses. (Right) SPARC may also increase the activating threshold of integrins and growth factors by inhibiting the binding of certain integrins to the ECM, opposing integrin-growth factor receptor clustering, and/or sequestering growth factors in the extracellular milieu. All of these effects result in a loss of communication and signal amplification of integrins and growth factor receptors, which reduces cellular responses. ECM composition, integrin profile, cytokine profile, cell-type and SPARC concentration/cell-surface localization are all factors dictating this differential response to SPARC

manipulating the tumor microenvironment to control cancer growth and metastasis.

Acknowledgements Supported by The Effie Marie Cain Scholarship in Angiogenesis Research (RAB), NIH grant R01CA118240 (RAB) and NIH training grant GM007062 (SAA). We gratefully acknowledge all members of the Brekken laboratory for their ongoing support. We would like to thank Lee B. Rivera, in particular, for his insightful discussion and feed-back during the development of a working model of SPARC function.

Competing Interests The authors have no competing interests to declare. 
Author Contributions SAA drafted the review, constructed the tables and conceptualized a working model. RAB edited and revised the review for intellectual content and continuity, as well as contributed to the development of a working model.

Open Access This article is distributed under the terms of the Creative Commons Attribution Noncommercial License which permits any noncommercial use, distribution, and reproduction in any medium, provided the original author(s) and source are credited.

\section{References}

Alonso SR, Tracey L, Ortiz P, Perez-Gomez B, Palacios J, Pollan M et al (2007) A high-throughput study in melanoma identifies epithelial-mesenchymal transition as a major determinant of metastasis. Cancer Res 67:3450-3460

Alvarez MJ, Prada F, Salvatierra E, Bravo AI, Lutzky VP, Carbone C et al (2005) Secreted protein acidic and rich in cysteine produced by human melanoma cells modulates polymorphonuclear leukocyte recruitment and antitumor cytotoxic capacity. Cancer Res 65:5123-5132

Amatschek S, Koenig U, Auer H, Steinlein P, Pacher M, Gruenfelder A et al (2004) Tissue-wide expression profiling using cDNA subtraction and microarrays to identify tumor-specific genes. Cancer Res 64:844-856

Arnold S, Mira E, Muneer S, Korpanty G, Beck AW, Holloway SE et al (2008) Forced expression of MMP9 rescues the loss of angiogenesis and abrogates metastasis of pancreatic tumors triggered by the absence of host SPARC. Exp Biol Med (Maywood) 233:860-873

Aycock RL, Bradshaw AC, Sage EH, Starcher B (2004) Development of UV-induced squamous cell carcinomas is suppressed in the absence of SPARC. J Invest Dermatol 123:592-599

Barker TH, Baneyx G, Cardo-Vila M, Workman GA, Weaver M, Menon PM et al (2005) SPARC regulates extracellular matrix organization through its modulation of integrin-linked kinase activity. J Biol Chem 280:36483-36493

Barth PJ, Moll R, Ramaswamy A (2005) Stromal remodeling and SPARC (secreted protein acid rich in cysteine) expression in invasive ductal carcinomas of the breast. Virchows Arch 446:532-536

Bassuk JA, Pichler R, Rothmier JD, Pippen J, Gordon K, Meek RL et al (2000) Induction of TGF-betal by the matricellular protein SPARC in a rat model of glomerulonephritis. Kidney Int 57:117-128

Beck AH, Espinosa I, Gilks CB, van de Rijn M, West RB (2008) The fibromatosis signature defines a robust stromal response in breast carcinoma. Lab Invest 88:591-601

Bellahcene A, Castronovo V (1995) Increased expression of osteonectin and osteopontin, two bone matrix proteins, in human breast cancer. Am J Pathol 146:95-100

Bergamaschi A, Tagliabue E, Sorlie T, Naume B, Triulzi T, Orlandi $\mathrm{R}$ et al (2008) Extracellular matrix signature identifies breast cancer subgroups with different clinical outcome. J Pathol 214:357-367

Berrier AL, Yamada KM (2007) Cell-matrix adhesion. J Cell Physiol 213:565-573

Best CJ, Gillespie JW, Yi Y, Chandramouli GV, Perlmutter MA, Gathright $\mathrm{Y}$ et al (2005) Molecular alterations in primary prostate cancer after androgen ablation therapy. Clin Cancer Res 11:6823-6834

Bloomston M, Ellison EC, Muscarella P, Al-Saif O, Martin EW, Melvin WS et al (2007) Stromal osteonectin overexpression is associated with poor outcome in patients with ampullary cancer. Ann Surg Oncol 14:211-217

Bornstein P (2001) Thrombospondins as matricellular modulators of cell function. J Clin Invest 107:929-934

Bornstein P (2002) Cell-matrix interactions: the view from the outside. Methods Cell Biol 69:7-11

Bornstein P, Sage EH (2002) Matricellular proteins: extracellular modulators of cell function. Curr Opin Cell Biol 14:608-616

Bosman FT, Stamenkovic I (2003) Functional structure and composition of the extracellular matrix. J Pathol 200:423-428

Brabender J, Marjoram P, Lord RV, Metzger R, Salonga D, Vallbohmer D et al (2005) The molecular signature of normal squamous esophageal epithelium identifies the presence of a field effect and can discriminate between patients with Barrett's esophagus and patients with Barrett's-associated adenocarcinoma. Cancer Epidemiol Biomarkers Prev 14:2113-2117

Bradshaw AD, Sage EH (2001) SPARC, a matricellular protein that functions in cellular differentiation and tissue response to injury. J Clin Invest 107:1049-1054

Bradshaw AD, Francki A, Motamed K, Howe C, Sage EH (1999) Primary mesenchymal cells isolated from SPARC-null mice exhibit altered morphology and rates of proliferation. Mol Biol Cell 10:1569-1579

Bradshaw AD, Reed MJ, Carbon JG, Pinney E, Brekken RA, Sage EH (2001) Increased fibrovascular invasion of subcutaneous polyvinyl alcohol sponges in SPARC-null mice. Wound Repair Regen 9:522-530

Bradshaw AD, Reed MJ, Sage EH (2002) SPARC-null mice exhibit accelerated cutaneous wound closure. J Histochem Cytochem 50:1-10

Bradshaw AD, Graves DC, Motamed K, Sage EH (2003a) SPARCnull mice exhibit increased adiposity without significant differences in overall body weight. Proc Natl Acad Sci USA 100:6045-6050

Bradshaw AD, Puolakkainen P, Dasgupta J, Davidson JM, Wight TN, Helene Sage E (2003b) SPARC-null mice display abnormalities in the dermis characterized by decreased collagen fibril diameter and reduced tensile strength. J Invest Dermatol 120:949-955

Bradshaw AD, Puolakkainen P, Dasgupta J, Davidson JM, Wight TN, Sage EH (2003c) SPARC-null mice display abnormalities in the dermis characterized by decreased collagen fibril diameter and reduced tensile strength. J Invest Dermatol 120:949-955

Brekken RA, Sage EH (2001) SPARC, a matricellular protein: at the crossroads of cell-matrix communication. Matrix Biol 19:816-827

Brekken RA, Puolakkainen P, Graves DC, Workman G, Lubkin SR, Sage EH (2003) Enhanced growth of tumors in SPARC null mice is associated with changes in the ECM. J Clin Invest 111:487-495

Briggs J, Chamboredon S, Castellazzi M, Kerry JA, Bos TJ (2002) Transcriptional upregulation of SPARC, in response to c-Jun overexpression, contributes to increased motility and invasion of MCF7 breast cancer cells. Oncogene 21:7077-7091

Brown TJ, Shaw PA, Karp X, Huynh MH, Begley H, Ringuette MJ (1999) Activation of SPARC expression in reactive stroma associated with human epithelial ovarian cancer. Gynecol Oncol $75: 25-33$

Brune K, Hong SM, Li A, Yachida S, Abe T, Griffith M et al (2008) Genetic and epigenetic alterations of familial pancreatic cancers. Cancer Epidemiol Biomarkers Prev 17:3536-3542

Bull Phelps SL, Carbon J, Miller A, Castro-Rivera E, Arnold S, Brekken RA et al (2009) Secreted protein acidic and rich in cysteine as a regulator of murine ovarian cancer growth and chemosensitivity. Am J Obstet Gynecol 200(180):e181-e187

Bullinger L, Dohner K, Bair E, Frohling S, Schlenk RF, Tibshirani R et al (2004) Use of gene-expression profiling to identify 
prognostic subclasses in adult acute myeloid leukemia. $\mathrm{N}$ Engl $\mathrm{J}$ Med 350:1605-1616

Campo McKnight DA, Sosnoski DM, Koblinski JE, Gay CV (2006) Roles of osteonectin in the migration of breast cancer cells into bone. J Cell Biochem 97:288-302

Che Y, Luo A, Wang H, Qi J, Guo J, Liu Z (2006) The differential expression of SPARC in esophageal squamous cell carcinoma. Int J Mol Med 17:1027-1033

Cheetham S, Tang MJ, Mesak F, Kennecke H, Owen D, Tai IT (2008) SPARC promoter hypermethylation in colorectal cancers can be reversed by 5 -Aza-2'deoxycytidine to increase SPARC expression and improve therapy response. Br J Cancer 98:1810-1819

Chen Y, Miller C, Mosher R, Zhao X, Deeds J, Morrissey M et al (2003) Identification of cervical cancer markers by cDNA and tissue microarrays. Cancer Res 63:1927-1935

Chen N, Ye XC, Chu K, Navone NM, Sage EH, Yu-Lee LY et al (2007) A secreted isoform of ErbB3 promotes osteonectin expression in bone and enhances the invasiveness of prostate cancer cells. Cancer Res 67:6544-6548

Chin D, Boyle GM, Williams RM, Ferguson K, Pandeya N, Pedley J et al (2005) Novel markers for poor prognosis in head and neck cancer. Int J Cancer 113:789-797

Chlenski A, Liu S, Crawford SE, Volpert OV, DeVries GH, Evangelista A et al (2002) SPARC is a key Schwannianderived inhibitor controlling neuroblastoma tumor angiogenesis. Cancer Res 62:7357-7363

Chlenski A, Liu S, Baker LJ, Yang Q, Tian Y, Salwen HR et al (2004) Neuroblastoma angiogenesis is inhibited with a folded synthetic molecule corresponding to the epidermal growth factor-like module of the follistatin domain of SPARC. Cancer Res 64:7420-7425

Chlenski A, Liu S, Guerrero LJ, Yang Q, Tian Y, Salwen HR et al (2006) SPARC expression is associated with impaired tumor growth, inhibited angiogenesis and changes in the extracellular matrix. Int J Cancer 118:310-316

Chlenski A, Guerrero LJ, Yang Q, Tian Y, Peddinti R, Salwen HR et al (2007) SPARC enhances tumor stroma formation and prevents fibroblast activation. Oncogene 26:4513-4522

Choi P, Jordan CD, Mendez E, Houck J, Yueh B, Farwell DG et al (2008) Examination of oral cancer biomarkers by tissue microarray analysis. Arch Otolaryngol Head Neck Surg 134:539-546

Clark CJ, Sage EH (2008) A prototypic matricellular protein in the tumor microenvironment - where there's SPARC, there's fire. J Cell Biochem 104:721-732

Dalla-Torre CA, Yoshimoto M, Lee CH, Joshua AM, de Toledo SR, Petrilli AS et al (2006) Effects of THBS3, SPARC and SPP1 expression on biological behavior and survival in patients with osteosarcoma. BMC Cancer 6:237

Davis GE, Senger DR (2005) Endothelial extracellular matrix: biosynthesis, remodeling, and functions during vascular morphogenesis and neovessel stabilization. Circ Res 97:1093-1107

De S, Chen J, Narizhneva NV, Heston W, Brainard J, Sage EH et al (2003) Molecular pathway for cancer metastasis to bone. J Biol Chem 278:39044-39050

Delany AM, Kalajzic I, Bradshaw AD, Sage EH, Canalis E (2003) Osteonectin-null mutation compromises osteoblast formation, maturation, and survival. Endocrinology 144:2588-2596

Desmouliere A, Guyot C, Gabbiani G (2004) The stroma reaction myofibroblast: a key player in the control of tumor cell behavior. Int J Dev Biol 48:509-517

Dhanesuan N, Sharp JA, Blick T, Price JT, Thompson EW (2002) Doxycycline-inducible expression of SPARC/Osteonectin/BM40 in MDA-MB-231 human breast cancer cells results in growth inhibition. Breast Cancer Res Treat 75:73-85

DiMartino JF, Lacayo NJ, Varadi M, Li L, Saraiya C, Ravindranath Y et al (2006) Low or absent SPARC expression in acute myeloid leukemia with MLL rearrangements is associated with sensitivity to growth inhibition by exogenous SPARC protein. Leukemia $20: 426-432$

Dvorak HF (1986) Tumors: wounds that do not heal. Similarities between tumor stroma generation and wound healing. N Engl J Med 315:1650-1659

Eliceiri BP (2001) Integrin and growth factor receptor crosstalk. Circ Res 89:1104-1110

Engbring JA, Kleinman HK (2003) The basement membrane matrix in malignancy. J Pathol 200:465-470

Fanburg-Smith JC, Bratthauer GL, Miettinen M (1999) Osteocalcin and osteonectin immunoreactivity in extraskeletal osteosarcoma: a study of 28 cases. Hum Pathol 30:32-38

Farrow B, Albo D, Berger DH (2008) The role of the tumor microenvironment in the progression of pancreatic cancer. J Surg Res 149:319-328

Ford R, Wang G, Jannati P, Adler D, Racanelli P, Higgins PJ et al (1993) Modulation of SPARC expression during butyrate-induced terminal differentiation of cultured human keratinocytes: regulation via a TGF-beta-dependent pathway. Exp Cell Res 206:261-275

Framson PE, Sage EH (2004) SPARC and tumor growth: where the seed meets the soil? J Cell Biochem 92:679-690

Francki A, Bradshaw AD, Bassuk JA, Howe CC, Couser WG, Sage EH (1999) SPARC regulates the expression of collagen type I and transforming growth factor-betal in mesangial cells. J Biol Chem 274:32145-32152

Francki A, McClure TD, Brekken RA, Motamed K, Murri C, Wang T et al (2004) SPARC regulates TGF-beta1-dependent signaling in primary glomerular mesangial cells. J Cell Biochem 91:915-925

Fromigue O, Louis K, Dayem M, Milanini J, Pages G, Tartare-Deckert $S$ et al (2003) Gene expression profiling of normal human pulmonary fibroblasts following coculture with non-small-cell lung cancer cells reveals alterations related to matrix degradation, angiogenesis, cell growth and survival. Oncogene 22:8487-8497

Fujita T, Shiba H, Sakata M, Uchida Y, Nakamura S, Kurihara H (2002) SPARC stimulates the synthesis of OPG/OCIF, MMP-2 and DNA in human periodontal ligament cells. J Oral Pathol Med 31:345-352

Gieseg MA, Cody T, Man MZ, Madore SJ, Rubin MA, Kaldjian EP (2002) Expression profiling of human renal carcinomas with functional taxonomic analysis. BMC Bioinformatics 3:26

Gilles C, Bassuk JA, Pulyaeva H, Sage EH, Foidart JM, Thompson EW (1998) SPARC/osteonectin induces matrix metalloproteinase 2 activation in human breast cancer cell lines. Cancer Res 58:5529-5536

Gilmour DT, Lyon GJ, Carlton MB, Sanes JR, Cunningham JM, Anderson JR et al (1998) Mice deficient for the secreted glycoprotein SPARC/osteonectin/BM40 develop normally but show severe age-onset cataract formation and disruption of the lens. Embo J 17:1860-1870

Goldenberg D, Ayesh S, Schneider T, Pappo O, Jurim O, Eid A et al (2002) Analysis of differentially expressed genes in hepatocellular carcinoma using cDNA arrays. Mol Carcinog 33:113-124

Golembieski WA, Ge S, Nelson K, Mikkelsen T, Rempel SA (1999) Increased SPARC expression promotes U87 glioblastoma invasion in vitro. Int J Dev Neurosci 17:463-472

Golembieski WA, Thomas SL, Schultz CR, Yunker CK, McClung HM, Lemke N et al (2008) HSP27 mediates SPARC-induced changes in glioma morphology, migration, and invasion. Glia 56:1061-1075

Gruber HE, Sage EH, Norton HJ, Funk S, Ingram J, Hanley EN Jr (2005) Targeted deletion of the SPARC gene accelerates disc degeneration in the aging mouse. J Histochem Cytochem 53:1131-1138

Guweidhi A, Kleeff J, Adwan H, Giese NA, Wente MN, Giese T et al (2005) Osteonectin influences growth and invasion of pancreatic cancer cells. Ann Surg 242:224-234 
Hasselaar P, Sage EH (1992) SPARC antagonizes the effect of basic fibroblast growth factor on the migration of bovine aortic endothelial cells. J Cell Biochem 49:272-283

Hedvat CV, Comenzo RL, Teruya-Feldstein J, Olshen AB, Ely SA, Osman K et al (2003) Insights into extramedullary tumour cell growth revealed by expression profiling of human plasmacytomas and multiple myeloma. Br J Haematol 122:728-744

Helleman J, Jansen MP, Ruigrok-Ritstier K, van Staveren IL, Look MP, Meijer-van Gelder ME et al (2008) Association of an extracellular matrix gene cluster with breast cancer prognosis and endocrine therapy response. Clin Cancer Res 14:5555-5564

Hong SM, Kelly D, Griffith M, Omura N, Li A, Li CP et al (2008) Multiple genes are hypermethylated in intraductal papillary mucinous neoplasms of the pancreas. Mod Pathol 21:1499-1507

Huang H, Colella S, Kurrer M, Yonekawa Y, Kleihues P, Ohgaki H (2000) Gene expression profiling of low-grade diffuse astrocytomas by cDNA arrays. Cancer Res 60:6868-6874

Huang DY, Lin YT, Jan PS, Hwang YC, Liang ST, Peng Y et al (2008) Transcription factor SOX-5 enhances nasopharyngeal carcinoma progression by down-regulating SPARC gene expression. J Pathol 214:445-455

Iacobuzio-Donahue CA, Argani P, Hempen PM, Jones J, Kern SE (2002) The desmoplastic response to infiltrating breast carcinoma: gene expression at the site of primary invasion and implications for comparisons between tumor types. Cancer Res 62:5351-5357

Ikuta Y, Nakatsura T, Kageshita T, Fukushima S, Ito S, Wakamatsu K et al (2005) Highly sensitive detection of melanoma at an early stage based on the increased serum secreted protein acidic and rich in cysteine and glypican-3 levels. Clin Cancer Res 11:8079-8088

Infante JR, Matsubayashi H, Sato N, Tonascia J, Klein AP, Riall TA et al (2007) Peritumoral fibroblast SPARC expression and patient outcome with resectable pancreatic adenocarcinoma. J Clin Oncol 25:319-325

Inoue H, Matsuyama A, Mimori K, Ueo H, Mori M (2002) Prognostic score of gastric cancer determined by cDNA microarray. Clin Cancer Res 8:3475-3479

Ioachim E, Charchanti A, Briasoulis E, Karavasilis V, Tsanou H, Arvanitis DL et al (2002) Immunohistochemical expression of extracellular matrix components tenascin, fibronectin, collagen type IV and laminin in breast cancer: their prognostic value and role in tumour invasion and progression. Eur J Cancer 38:2362-2370

Jacob K, Webber M, Benayahu D, Kleinman HK (1999) Osteonectin promotes prostate cancer cell migration and invasion: a possible mechanism for metastasis to bone. Cancer Res 59:4453-4457

Jones C, Mackay A, Grigoriadis A, Cossu A, Reis-Filho JS, Fulford L et al (2004) Expression profiling of purified normal human luminal and myoepithelial breast cells: identification of novel prognostic markers for breast cancer. Cancer Res 64:3037-3045

Joyce JA, Pollard JW (2009) Microenvironmental regulation of metastasis. Nat Rev Cancer 9:239-252

Juliano RL (2002) Signal transduction by cell adhesion receptors and the cytoskeleton: functions of integrins, cadherins, selectins, and immunoglobulin-superfamily members. Annu Rev Pharmacol Toxicol 42:283-323

Jung YD, Ahmad SA, Liu W, Reinmuth N, Parikh A, Stoeltzing O et al (2002) The role of the microenvironment and intercellular cross-talk in tumor angiogenesis. Semin Cancer Biol 12:105-112

Kahn SL, Ronnett BM, Gravitt PE, Gustafson KS (2008) Quantitative methylation-specific PCR for the detection of aberrant DNA methylation in liquid-based Pap tests. Cancer 114:57-64

Kaiser S, Park YK, Franklin JL, Halberg RB, Yu M, Jessen WJ et al (2007) Transcriptional recapitulation and subversion of embryonic colon development by mouse colon tumor models and human colon cancer. Genome Biol 8:R131

Kato Y, Sakai N, Baba M, Kaneko S, Kondo K, Kubota Y et al (1998) Stimulation of motility of human renal cell carcinoma by
SPARC/Osteonectin/BM-40 associated with type IV collagen. Invasion Metastasis 18:105-114

Kato Y, Frankenne F, Noel A, Sakai N, Nagashima Y, Koshika S et al (2000) High production of SPARC/osteonectin/BM-40 in mouse metastatic B16 melanoma cell lines. Pathol Oncol Res 6:24-26

Kato Y, Lewalle JM, Baba Y, Tsukuda M, Sakai N, Baba M et al (2001) Induction of SPARC by VEGF in human vascular endothelial cells. Biochem Biophys Res Commun 287:422426

Kato Y, Nagashima Y, Baba Y, Kawano T, Furukawa M, Kubota A et al (2005) Expression of SPARC in tongue carcinoma of stage II is associated with poor prognosis: an immunohistochemical study of 86 cases. Int J Mol Med 16:263-268

Koblinski JE, Kaplan-Singer BR, VanOsdol SJ, Wu M, Engbring JA, Wang $\mathrm{S}$ et al (2005) Endogenous osteonectin/SPARC/BM-40 expression inhibits MDA-MB-231 breast cancer cell metastasis. Cancer Res 65:7370-7377

Koukourakis MI, Giatromanolaki A, Brekken RA, Sivridis E, Gatter $\mathrm{KC}$, Harris AL et al (2003) Enhanced expression of SPARC/ osteonectin in the tumor-associated stroma of non-small cell lung cancer is correlated with markers of hypoxia/acidity and with poor prognosis of patients. Cancer Res 63:5376-5380

Kram A, Li L, Zhang RD, Yoon DS, Ro JY, Johnston D et al (2001) Mapping and genome sequence analysis of chromosome 5 regions involved in bladder cancer progression. Lab Invest 81:1039-1048

Kumar S, Weaver VM (2009) Mechanics, malignancy, and metastasis: the force journey of a tumor cell. Cancer Metastasis Rev 28: $113-127$

Kunigal S, Gondi CS, Gujrati M, Lakka SS, Dinh DH, Olivero WC et al (2006) SPARC-induced migration of glioblastoma cell lines via uPA-uPAR signaling and activation of small GTPase RhoA. Int J Oncol 29:1349-1357

Kuphal S, Palm HG, Poser I, Bosserhoff AK (2005) Snail-regulated genes in malignant melanoma. Melanoma Res 15:305-313

Kupprion C, Motamed K, Sage EH (1998) SPARC (BM-40, osteonectin) inhibits the mitogenic effect of vascular endothelial growth factor on microvascular endothelial cells. J Biol Chem 273:29635-29640

Lapointe J, Li C, Higgins JP, van de Rijn M, Bair E, Montgomery K et al (2004) Gene expression profiling identifies clinically relevant subtypes of prostate cancer. Proc Natl Acad Sci USA 101:811816

Larsen M, Artym VV, Green JA, Yamada KM (2006) The matrix reorganized: extracellular matrix remodeling and integrin signaling. Curr Opin Cell Biol 18:463-471

Lau CP, Poon RT, Cheung ST, Yu WC, Fan ST (2006) SPARC and Hevin expression correlate with tumour angiogenesis in hepatocellular carcinoma. J Pathol 210:459-468

Le Bail B, Faouzi S, Boussarie L, Guirouilh J, Blanc JF, Carles J et al (1999) Osteonectin/SPARC is overexpressed in human hepatocellular carcinoma. J Pathol 189:46-52

Ledda F, Bravo AI, Adris S, Bover L, Mordoh J, Podhajcer OL (1997a) The expression of the secreted protein acidic and rich in cysteine (SPARC) is associated with the neoplastic progression of human melanoma. J Invest Dermatol 108:210-214

Ledda MF, Adris S, Bravo AI, Kairiyama C, Bover L, Chernajovsky $\mathrm{Y}$ et al (1997b) Suppression of SPARC expression by antisense RNA abrogates the tumorigenicity of human melanoma cells. Nat Med 3:171-176

Lien HC, Hsiao YH, Lin YS, Yao YT, Juan HF, Kuo WH et al (2007) Molecular signatures of metaplastic carcinoma of the breast by large-scale transcriptional profiling: identification of genes potentially related to epithelial-mesenchymal transition. Oncogene 26:7859-7871

Liotta LA, Kohn EC (2001) The microenvironment of the tumour-host interface. Nature 411:375-379 
Lorusso G, Ruegg C (2008) The tumor microenvironment and its contribution to tumor evolution toward metastasis. Histochem Cell Biol 130:1091-1103

Luo A, Kong J, Hu G, Liew CC, Xiong M, Wang X et al (2004) Discovery of $\mathrm{Ca} 2+$-relevant and differentiation-associated genes downregulated in esophageal squamous cell carcinoma using cDNA microarray. Oncogene 23:1291-1299

Lussier C, Sodek J, Beaulieu JF (2001) Expression of SPARC/ osteonectin/BM4O in the human gut: predominance in the stroma of the remodeling distal intestine. J Cell Biochem 81:463-476

Madoz-Gurpide J, Lopez-Serra P, Martinez-Torrecuadrada JL, Sanchez L, Lombardia L, Casal JI (2006) Proteomics-based validation of genomic data: applications in colorectal cancer diagnosis. Mol Cell Proteomics 5:1471-1483

Maeng HY, Choi DK, Takeuchi M, Yamamoto M, Tominaga M, Tsukamoto T et al (2002a) Appearance of osteonectin-expressing fibroblastic cells in early rat stomach carcinogenesis and stomach tumors induced with N-methyl-N'-nitro-N-nitrosoguanidine. Jpn J Cancer Res 93:960-967

Maeng HY, Song SB, Choi DK, Kim KE, Jeong HY, Sakaki Y et al (2002b) Osteonectin-expressing cells in human stomach cancer and their possible clinical significance. Cancer Lett 184:117-121

Mantoni TS, Schendel RR, Rodel F, Niedobitek G, Al-Assar O, Masamune A et al (2008) Stromal SPARC expression and patient survival after chemoradiation for non-resectable pancreatic adenocarcinoma. Cancer Biol Ther 7:1806-1815

Martinez N, Camacho FI, Algara P, Rodriguez A, Dopazo A, RuizBallesteros E et al (2003) The molecular signature of mantle cell lymphoma reveals multiple signals favoring cell survival. Cancer Res 63:8226-8232

Massi D, Franchi A, Borgognoni L, Reali UM, Santucci M (1999) Osteonectin expression correlates with clinical outcome in thin cutaneous malignant melanomas. Hum Pathol 30:339-344

McClung HM, Thomas SL, Osenkowski P, Toth M, Menon P, Raz A et al (2007) SPARC upregulates MT1-MMP expression, MMP-2 activation, and the secretion and cleavage of galectin-3 in U87MG glioma cells. Neurosci Lett 419:172-177

Mendis DB, Ivy GO, Brown IR (1998) SPARC/osteonectin mRNA is induced in blood vessels following injury to the adult rat cerebral cortex. Neurochem Res 23:1117-1123

Minn AJ, Gupta GP, Siegel PM, Bos PD, Shu W, Giri DD et al (2005) Genes that mediate breast cancer metastasis to lung. Nature 436:518-524

Mitas M, Almeida JS, Mikhitarian K, Gillanders WE, Lewin DN, Spyropoulos DD et al (2005) Accurate discrimination of Barrett's esophagus and esophageal adenocarcinoma using a quantitative three-tiered algorithm and multimarker real-time reverse transcription-PCR. Clin Cancer Res 11:2205-2214

Mok SC, Chan WY, Wong KK, Muto MG, Berkowitz RS (1996) SPARC, an extracellular matrix protein with tumor-suppressing activity in human ovarian epithelial cells. Oncogene 12:18951901

Moser M, Legate KR, Zent R, Fassler R (2009) The tail of integrins, talin, and kindlins. Science 324:895-899

Motamed K, Funk SE, Koyama H, Ross R, Raines EW, Sage EH (2002) Inhibition of PDGF-stimulated and matrix-mediated proliferation of human vascular smooth muscle cells by SPARC is independent of changes in cell shape or cyclin-dependent kinase inhibitors. J Cell Biochem 84:759-771

Motamed K, Blake DJ, Angello JC, Allen BL, Rapraeger AC, Hauschka SD et al (2003) Fibroblast growth factor receptor-1 mediates the inhibition of endothelial cell proliferation and the promotion of skeletal myoblast differentiation by SPARC: a role for protein kinase A. J Cell Biochem 90:408-423

Nie J, Chang B, Traktuev DO, Sun J, March K, Chan L et al (2008) IFATS collection: combinatorial peptides identify alpha5beta1 integrin as a receptor for the matricellular protein SPARC on adipose stromal cells. Stem Cells 26:2735-2745

Nimphius W, Moll R, Olbert P, Ramaswamy A, Barth PJ (2007) $\mathrm{CD} 34+$ fibrocytes in chronic cystitis and noninvasive and invasive urothelial carcinomas of the urinary bladder. Virchows Arch 450:179-185

Norose K, Clark JI, Syed NA, Basu A, Heber-Katz E, Sage EH et al (1998) SPARC deficiency leads to early-onset cataractogenesis. Invest Ophthalmol Vis Sci 39:2674-2680

Nozaki M, Sakurai E, Raisler BJ, Baffi JZ, Witta J, Ogura Y et al (2006) Loss of SPARC-mediated VEGFR-1 suppression after injury reveals a novel antiangiogenic activity of VEGF-A. J Clin Invest 116:422-429

Paley PJ, Goff BA, Gown AM, Greer BE, Sage EH (2000) Alterations in SPARC and VEGF immunoreactivity in epithelial ovarian cancer. Gynecol Oncol 78:336-341

Pan MR, Chang HC, Chuang LY, Hung WC (2008) The nonsteroidal anti-inflammatory drug NS398 reactivates SPARC expression via promoter demethylation to attenuate invasiveness of lung cancer cells. Exp Biol Med (Maywood) 233:456-462

Parker BS, Argani P, Cook BP, Liangfeng H, Chartrand SD, Zhang M et al (2004) Alterations in vascular gene expression in invasive breast carcinoma. Cancer Res 64:7857-7866

Pavasant P, Yongchaitrakul T, Pattamapun K, Arksornnukit M (2003) The synergistic effect of TGF-beta and 1,25-dihydroxyvitamin D3 on SPARC synthesis and alkaline phosphatase activity in human pulp fibroblasts. Arch Oral Biol 48:717-722

Pen A, Moreno MJ, Martin J, Stanimirovic DB (2007) Molecular markers of extracellular matrix remodeling in glioblastoma vessels: microarray study of laser-captured glioblastoma vessels. Glia 55:559-572

Podhajcer OL, Benedetti LG, Girotti MR, Prada F, Salvatierra E, Llera AS (2008) The role of the matricellular protein SPARC in the dynamic interaction between the tumor and the host. Cancer Metastasis Rev 27:691-705

Porte H, Chastre E, Prevot S, Nordlinger B, Empereur S, Basset P et al (1995) Neoplastic progression of human colorectal cancer is associated with overexpression of the stromelysin-3 and BM-40/ SPARC genes. Int J Cancer 64:70-75

Porte H, Triboulet JP, Kotelevets L, Carrat F, Prevot S, Nordlinger B et al (1998) Overexpression of stromelysin-3, BM-40/SPARC, and MET genes in human esophageal carcinoma: implications for prognosis. Clin Cancer Res 4:1375-1382

Porter JC, Hogg N (1998) Integrins take partners: cross-talk between integrins and other membrane receptors. Trends Cell Biol 8:390-396

Porter PL, Sage EH, Lane TF, Funk SE, Gown AM (1995) Distribution of SPARC in normal and neoplastic human tissue. J Histochem Cytochem 43:791-800

Porter D, Lahti-Domenici J, Keshaviah A, Bae YK, Argani P, Marks J et al (2003) Molecular markers in ductal carcinoma in situ of the breast. Mol Cancer Res 1:362-375

Prada F, Benedetti LG, Bravo AI, Alvarez MJ, Carbone C, Podhajcer OL (2007) SPARC endogenous level, rather than fibroblastproduced SPARC or stroma reorganization induced by SPARC, is responsible for melanoma cell growth. J Invest Dermatol 127:2618-2628

Prenzel KL, Warnecke-Eberz U, Xi H, Brabender J, Baldus SE, Bollschweiler E et al (2006) Significant overexpression of SPARC/osteonectin mRNA in pancreatic cancer compared to cancer of the papilla of Vater. Oncol Rep 15:1397-1401

Puolakkainen P, Bradshaw AD, Kyriakides TR, Reed M, Brekken R, Wight $T$ et al (2003) Compromised production of extracellular matrix in mice lacking secreted protein, acidic and rich in cysteine (SPARC) leads to a reduced foreign body reaction to implanted biomaterials. Am J Pathol 162:627-635 
Puolakkainen PA, Brekken RA, Muneer S, Sage EH (2004) Enhanced growth of pancreatic tumors in SPARC-null mice is associated with decreased deposition of extracellular matrix and reduced tumor cell apoptosis. Mol Cancer Res 2:215-224

Raines EW, Lane TF, Iruela-Arispe ML, Ross R, Sage EH (1992) The extracellular glycoprotein SPARC interacts with platelet-derived growth factor (PDGF)-AB and -BB and inhibits the binding of PDGF to its receptors. Proc Natl Acad Sci USA 89:1281-1285

Reed MJ, Puolakkainen P, Lane TF, Dickerson D, Bornstein P, Sage EH (1993) Differential expression of SPARC and thrombospondin 1 in wound repair: immunolocalization and in situ hybridization. J Histochem Cytochem 41:1467-1477

Reed MJ, Vernon RB, Abrass IB, Sage EH (1994) TGF-beta 1 induces the expression of type I collagen and SPARC, and enhances contraction of collagen gels, by fibroblasts from young and aged donors. J Cell Physiol 158:169-179

Rempel SA, Golembieski WA, Ge S, Lemke N, Elisevich K, Mikkelsen T et al (1998) SPARC: a signal of astrocytic neoplastic transformation and reactive response in human primary and xenograft gliomas. J Neuropathol Exp Neurol 57:1112-1121

Rempel SA, Ge S, Gutierrez JA (1999) SPARC: a potential diagnostic marker of invasive meningiomas. Clin Cancer Res 5:237-241

Rempel SA, Golembieski WA, Fisher JL, Maile M, Nakeff A (2001) SPARC modulates cell growth, attachment and migration of U87 glioma cells on brain extracellular matrix proteins. J Neurooncol 53:149-160

Rich JN, Shi Q, Hjelmeland M, Cummings TJ, Kuan CT, Bigner DD et al (2003) Bone-related genes expressed in advanced malignancies induce invasion and metastasis in a genetically defined human cancer model. J Biol Chem 278:15951-15957

Rich JN, Hans C, Jones B, Iversen ES, McLendon RE, Rasheed BK et al (2005) Gene expression profiling and genetic markers in glioblastoma survival. Cancer Res 65:4051-4058

Robert G, Gaggioli C, Bailet O, Chavey C, Abbe P, Aberdam E et al (2006) SPARC represses E-cadherin and induces mesenchymal transition during melanoma development. Cancer Res 66:7516-7523

Rodriguez-Jimenez FJ, Caldes T, Iniesta P, Vidart JA, Garcia-Asenjo JL, Benito M (2007) Overexpression of SPARC protein contrasts with its transcriptional silencing by aberrant hypermethylation of SPARC CpG-rich region in endometrial carcinoma. Oncol Rep 17:1301-1307

Ross ME, Mahfouz R, Onciu M, Liu HC, Zhou X, Song G et al (2004) Gene expression profiling of pediatric acute myelogenous leukemia. Blood 104:3679-3687

Rumpler G, Becker B, Hafner C, McClelland M, Stolz W, Landthaler $M$ et al (2003) Identification of differentially expressed genes in models of melanoma progression by cDNA array analysis: SPARC, MIF and a novel cathepsin protease characterize aggressive phenotypes. Exp Dermatol 12:761-771

Ryu B, Jones J, Hollingsworth MA, Hruban RH, Kern SE (2001) Invasion-specific genes in malignancy: serial analysis of gene expression comparisons of primary and passaged cancers. Cancer Res 61:1833-1838

Sage H, Vernon RB, Funk SE, Everitt EA, Angello J (1989) SPARC, a secreted protein associated with cellular proliferation, inhibits cell spreading in vitro and exhibits $\mathrm{Ca}+2$-dependent binding to the extracellular matrix. J Cell Biol 109:341-356

Said N, Motamed K (2005) Absence of host-secreted protein acidic and rich in cysteine (SPARC) augments peritoneal ovarian carcinomatosis. Am J Pathol 167:1739-1752

Sakai N, Baba M, Nagasima Y, Kato Y, Hirai K, Kondo K et al (2001) SPARC expression in primary human renal cell carcinoma: upregulation of SPARC in sarcomatoid renal carcinoma. Hum Pathol 32:1064-1070
Said N, Najwer I, Motamed K (2007a) Secreted protein acidic and rich in cysteine (SPARC) inhibits integrin-mediated adhesion and growth factor-dependent survival signaling in ovarian cancer. Am J Pathol 170:1054-1063

Said N, Socha MJ, Olearczyk JJ, Elmarakby AA, Imig JD, Motamed K (2007b) Normalization of the ovarian cancer microenvironment by SPARC. Mol Cancer Res 5:1015-1030

Sangaletti S, Stoppacciaro A, Guiducci C, Torrisi MR, Colombo MP (2003) Leukocyte, rather than tumor-produced SPARC, determines stroma and collagen type IV deposition in mammary carcinoma. J Exp Med 198:1475-1485

Sangaletti S, Di Carlo E, Gariboldi S, Miotti S, Cappetti B, Parenza M et al (2008) Macrophage-derived SPARC bridges tumor cellextracellular matrix interactions toward metastasis. Cancer Res 68:9050-9059

Sansom OJ, Mansergh FC, Evans MJ, Wilkins JA, Clarke AR (2007) Deficiency of SPARC suppresses intestinal tumorigenesis in APCMin/+ mice. Gut 56:1410-1414

Sarrio D, Rodriguez-Pinilla SM, Hardisson D, Cano A, MorenoBueno G, Palacios J (2008) Epithelial-mesenchymal transition in breast cancer relates to the basal-like phenotype. Cancer Res 68:989-997

Sasaki T, Hohenester E, Gohring W, Timpl R (1998) Crystal structure and mapping by site-directed mutagenesis of the collagenbinding epitope of an activated form of BM-40/SPARC/osteonectin. EMBO J 17:1625-1634

Sasaki T, Miosge N, Timpl R (1999) Immunochemical and tissue analysis of protease generated neoepitopes of BM-40 (osteonectin, SPARC) which are correlated to a higher affinity binding to collagens. Matrix Biol 18:499-508

Sato N, Fukushima N, Maehara N, Matsubayashi H, Koopmann J, $\mathrm{Su}$ GH et al (2003) SPARC/osteonectin is a frequent target for aberrant methylation in pancreatic adenocarcinoma and a mediator of tumor-stromal interactions. Oncogene 22:50215030

Schiemann BJ, Neil JR, Schiemann WP (2003) SPARC inhibits epithelial cell proliferation in part through stimulation of the transforming growth factor-beta-signaling system. Mol Biol Cell 14:3977-3988

Schultz GS, Wysocki A (2009) Interactions between extracellular matrix and growth factors in wound healing. Wound Repair Regen 17:153-162

Schulz A, Loreth B, Battmann A, Knoblauch B, Stahl U, Pollex U et al (1998) Bone matrix production in osteosarcoma. Verh Dtsch Ges Pathol 82:144-153

Schultz C, Lemke N, Ge S, Golembieski WA, Rempel SA (2002) Secreted protein acidic and rich in cysteine promotes glioma invasion and delays tumor growth in vivo. Cancer Res 62:6270-6277

Seno T, Harada H, Kohno S, Teraoka M, Inoue A, Ohnishi T (2009) Downregulation of SPARC expression inhibits cell migration and invasion in malignant gliomas. Int J Oncol 34:707-715

Shan W, Yang G, Liu J (2009) The inflammatory network: bridging senescent stroma and epithelial tumorigenesis. Front Biosci 14:4044-4057

Shankavaram UT, DeWitt DL, Funk SE, Sage EH, Wahl LM (1997) Regulation of human monocyte matrix metalloproteinases by SPARC. J Cell Physiol 173:327-334

Shi Q, Bao S, Maxwell JA, Reese ED, Friedman HS, Bigner DD et al (2004) Secreted protein acidic, rich in cysteine (SPARC), mediates cellular survival of gliomas through AKT activation. $\mathrm{J}$ Biol Chem 279:52200-52209

Shi Q, Bao S, Song L, Wu Q, Bigner DD, Hjelmeland AB et al (2007) Targeting SPARC expression decreases glioma cellular survival and invasion associated with reduced activities of FAK and ILK kinases. Oncogene 26:4084-4094 
Siddiq F, Sarkar FH, Wali A, Pass HI, Lonardo F (2004) Increased osteonectin expression is associated with malignant transformation and tumor associated fibrosis in the lung. Lung Cancer 45:197-205

Smit DJ, Gardiner BB, Sturm RA (2007) Osteonectin downregulates E-cadherin, induces osteopontin and focal adhesion kinase activity stimulating an invasive melanoma phenotype. Int $\mathrm{J}$ Cancer 121:2653-2660

Socha MJ, Said N, Dai Y, Kwong J, Ramalingam P, Trieu V et al (2009) Aberrant promoter methylation of SPARC in ovarian cancer. Neoplasia 11:126-135

Somanath PR, Ciocea A, Byzova TV (2009) Integrin and growth factor receptor alliance in angiogenesis. Cell Biochem Biophys 53:53-64

Sosa MS, Girotti MR, Salvatierra E, Prada F, de Olmo JA, Gallango SJ et al (2007) Proteomic analysis identified N-cadherin, clusterin, and HSP27 as mediators of SPARC (secreted protein, acidic and rich in cysteines) activity in melanoma cells. Proteomics 7:4123-4134

Sova P, Feng Q, Geiss G, Wood T, Strauss R, Rudolf V et al (2006) Discovery of novel methylation biomarkers in cervical carcinoma by global demethylation and microarray analysis. Cancer Epidemiol Biomarkers Prev 15:114-123

St Croix B, Rago C, Velculescu V, Traverso G, Romans KE, Montgomery E et al (2000) Genes expressed in human tumor endothelium. Science 289:1197-1202

Streuli CH (2009) Integrins and cell-fate determination. J Cell Sci 122:171-177

Streuli CH, Akhtar N (2009) Signal co-operation between integrins and other receptor systems. Biochem J 418:491-506

Stupack DG (2007) The biology of integrins. Oncology (Williston Park) 21:6-12

Sturm RA, Satyamoorthy K, Meier F, Gardiner BB, Smit DJ, Vaidya $\mathrm{B}$ et al (2002) Osteonectin/SPARC induction by ectopic beta(3) integrin in human radial growth phase primary melanoma cells. Cancer Res 62:226-232

Suzuki M, Hao C, Takahashi T, Shigematsu H, Shivapurkar N, Sathyanarayana UG et al (2005) Aberrant methylation of SPARC in human lung cancers. Br J Cancer 92:942-948

Taghizadeh F, Tang MJ, Tai IT (2007) Synergism between vitamin D and secreted protein acidic and rich in cysteine-induced apoptosis and growth inhibition results in increased susceptibility of therapy-resistant colorectal cancer cells to chemotherapy. Mol Cancer Ther 6:309-317

Tai IT, Dai M, Owen DA, Chen LB (2005) Genome-wide expression analysis of therapy-resistant tumors reveals SPARC as a novel target for cancer therapy. J Clin Invest 115:1492-1502

Takano T, Hasegawa Y, Miyauchi A, Matsuzuka F, Yoshida H, Kuma $\mathrm{K}$ et al (2002) Quantitative analysis of osteonectin mRNA in thyroid carcinomas. Endocr J 49:511-516

Takeno A, Takemasa I, Doki Y, Yamasaki M, Miyata H, Takiguchi S et al (2008) Integrative approach for differentially overexpressed genes in gastric cancer by combining large-scale gene expression profiling and network analysis. Br J Cancer 99:13071315

Thomas R, True LD, Bassuk JA, Lange PH, Vessella RL (2000) Differential expression of osteonectin/SPARC during human prostate cancer progression. Clin Cancer Res 6:1140-1149

Tian M, Schiemann WP (2009) The TGF-beta paradox in human cancer: an update. Future Oncol 5:259-271

Timar J, Lapis K, Dudas J, Sebestyen A, Kopper L, Kovalszky I (2002) Proteoglycans and tumor progression: Janus-faced molecules with contradictory functions in cancer. Semin Cancer Biol 12:173-186

Verrecchia F, Mauviel A (2007) Transforming growth factor-beta and fibrosis. World J Gastroenterol 13:3056-3062
Volmer MW, Radacz Y, Hahn SA, Klein-Scory S, Stuhler K, Zapatka $M$ et al (2004) Tumor suppressor Smad4 mediates downregulation of the anti-adhesive invasion-promoting matricellular protein SPARC: Landscaping activity of Smad4 as revealed by a "secretome" analysis. Proteomics 4:1324-1334

Wang CS, Lin KH, Chen SL, Chan YF, Hsueh S (2004) Overexpression of SPARC gene in human gastric carcinoma and its clinic-pathologic significance. Br J Cancer 91:1924-1930

Wang Y, Yu Q, Cho AH, Rondeau G, Welsh J, Adamson E et al (2005) Survey of differentially methylated promoters in prostate cancer cell lines. Neoplasia 7:748-760

Watkins G, Douglas-Jones A, Bryce R, Mansel RE, Jiang WG (2005) Increased levels of SPARC (osteonectin) in human breast cancer tissues and its association with clinical outcomes. Prostaglandins Leukot Essent Fatty Acids 72:267-272

Weaver MS, Workman G, Sage EH (2008) The copper binding domain of SPARC mediates cell survival in vitro via interaction with integrin betal and activation of integrin-linked kinase. J Biol Chem 283:22826-22837

Wernert N (1997) The multiple roles of tumour stroma. Virchows Arch 430:433-443

Wewer UM, Albrechtsen R, Fisher LW, Young MF, Termine JD (1988) Osteonectin/SPARC/BM-40 in human decidua and carcinoma, tissues characterized by de novo formation of basement membrane. Am J Pathol 132:345-355

Whiteside TL (2008) The tumor microenvironment and its role in promoting tumor growth. Oncogene 27:5904-5912

Wiese AH, Auer J, Lassmann S, Nahrig J, Rosenberg R, Hofler H et al (2007) Identification of gene signatures for invasive colorectal tumor cells. Cancer Detect Prev 31:282-295

Woelfle U, Cloos J, Sauter G, Riethdorf L, Janicke F, van Diest P et al (2003) Molecular signature associated with bone marrow micrometastasis in human breast cancer. Cancer Res 63:5679-5684

Wong FH, Huang CY, Su LJ, Wu YC, Lin YS, Hsia JY et al (2009) Combination of microarray profiling and protein-protein interaction databases delineates the minimal discriminators as a metastasis network for esophageal squamous cell carcinoma. Int J Oncol 34:117-128

Wrana JL, Overall CM, Sodek J (1991) Regulation of the expression of a secreted acidic protein rich in cysteine (SPARC) in human fibroblasts by transforming growth factor beta. Comparison of transcriptional and post-transcriptional control with fibronectin and type I collagen. Eur J Biochem 197:519-528

Xue LY, Hu N, Song YM, Zou SM, Shou JZ, Qian LX et al (2006) Tissue microarray analysis reveals a tight correlation between protein expression pattern and progression of esophageal squamous cell carcinoma. BMC Cancer 6:296

Yamanaka M, Kanda K, Li NC, Fukumori T, Oka N, Kanayama HO et al (2001) Analysis of the gene expression of SPARC and its prognostic value for bladder cancer. J Urol 166:2495-2499

Yamashita K, Upadhay S, Mimori K, Inoue H, Mori M (2003) Clinical significance of secreted protein acidic and rich in cystein in esophageal carcinoma and its relation to carcinoma progression. Cancer 97:2412-2419

Yan Q, Clark JI, Wight TN, Sage EH (2002) Alterations in the lens capsule contribute to cataractogenesis in SPARC-null mice. J Cell Sci 115:2747-2756

Yan Q, Blake D, Clark JI, Sage EH (2003) Expression of the matricellular protein SPARC in murine lens: SPARC is necessary for the structural integrity of the capsular basement membrane. J Histochem Cytochem 51:503-511

Yang E, Kang HJ, Koh KH, Rhee H, Kim NK, Kim H (2007) Frequent inactivation of SPARC by promoter hypermethylation in colon cancers. Int J Cancer 121:567-575 
Yiu GK, Chan WY, Ng SW, Chan PS, Cheung KK, Berkowitz RS et al (2001) SPARC (secreted protein acidic and rich in cysteine) induces apoptosis in ovarian cancer cells. Am J Pathol 159:609-622

Yunker CK, Golembieski W, Lemke N, Schultz CR, Cazacu S, Brodie $\mathrm{C}$ et al (2008) SPARC-induced increase in glioma matrix and decrease in vascularity are associated with reduced VEGF expression and secretion. Int J Cancer 122:2735-2743
Zajchowski DA, Bartholdi MF, Gong Y, Webster L, Liu HL, Munishkin A et al (2001) Identification of gene expression profiles that predict the aggressive behavior of breast cancer cells. Cancer Res 61:5168-5178

Zalatnai A (2006) Molecular aspects of stromal-parenchymal interactions in malignant neoplasms. Curr Mol Med 6:685693 